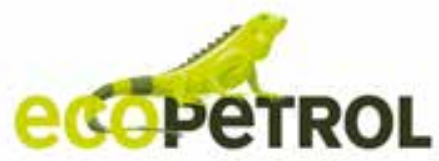

ctyf@ecopetrol.com.co

\title{
ORIGIN OF A DOUBLE FOREARC BASIN: THE EXAMPLE OF THE TUMACO - MANGLARES BASIN, NORTHWESTERN SOUTHAMERICA
}

\author{
ORIGEN DE UNA \\ CUENCA DE \\ ANTEARCO DOBLE: \\ EJEMPLO DE LA \\ CUENCA DE TUMACO \\ - MANGLARES, \\ NOROCCIDENTE DE \\ SURAMERICA
}

López-Ramos, Eduardo $a^{a^{*}}$

\section{ABSTRACT}

The subsidence and uplift history of the forearc system of southwestern Colombia and northern Ecuador margin is complex and reveals several stages of deformation. The sequential stratigraphy of the forearc area shows the development of three megasequences ( $M 1$ to $M 3$ ). The basal megasequence corresponds to the basement of the forearc, which was formed at the end of the Mesozoic and at the beginning of the Cenozoic and accreted against the Northwestern part of South America related to the accretion of the Late Cretaceous - Paleocene oceanic plateau. This accretion occurred in a transpressional regime. The second megasequence is composed by deep water sediments, recording the transition between transpressional to compressional stages of the margin from the Late Eocene to the Middle Miocene. The third megasequence is characterized by shallow water sediments strongly constrained by the compressional stage of the margin and the uplift activity of the structural highs since the Late Miocene up to present. The structural geometry of the margin is characterized by basement thrusts that deformed the forearc crust. Westward, the forearc zone -according to the support of the overriding plate -is divided into mantle wedge and lower plate domains. The margin evolution suggests that the subducting plate geodynamical changes affect strongly the interplate coupling and mantle wedge and produce changes in the subsidence or uplift through the double forearc basin systems.

\section{RESUMEN}

La historia de subsidencia y levantamiento del Sistema de antearco de la margen SW de Colombia y Norte de Ecuador es compleja y revela numerosos estados de deformación. La estratigrafía secuencial de la zona de antearco evidencia el desarrollo de tres megasecuencias (M1 a M3). La megasecuencia basal está relacionada con la acreción de una meseta oceánica formada a finales del Mesozoico a principios del Cenozoico correspondiente al basamento de la zona de antearco. Esta acreción ocurre en un estado de régimen transpresional. La segunda megasecuencia está compuesta por sedimentos de aguas profundas, registrando la transición entre los estados transpresionales a compresionales de la margen desde finales del Eoceno hasta mediados del Mioceno. La tercer megasecuencia se caracteriza por sedimentos acumulados en ámbitos sedimentarios poco profundos con una fuerte incidencia del estado compresional de la margen y la actividad de levantamiento de los altos estructurales desde finales del Mioceno hasta el reciente. La geometría estructural de la margen es caracterizada por cabalgamientos de escamación gruesa que deforman la corteza del antearco. El borde occidental de la zona de antearco, de acuerdo al soporte que tenga la placa superior, se puede dividir en un dominio soportado por la cuña mantelica y un dominio soportado por la placa subyacente. La evolución de la margen sugiere que los cambios geodinámicos de la placa subducente afecta fuertemente el contacto interplaca y la cuña mantelica, y produce cambios en la subsidencia o levantamiento a través del sistema de cuencas de antearco doble.

\section{KEYWORDS / PALABRAS CLAVE}

AFFILIATION

Forearc basin | Megasequences |

Subduction | Mantle wedge |

Cuenca de antearco | Megasecuencia |

Subducción | Cuña de manto |
Ecopetrol, Vicepresidencia de Exploración,
42 Edificio San Martín, Piso 10, Bogotá D. C. Carrera 7 \# 32-42 Edificio San Martín, Piso 10, Bogotá D. C. 


\section{INTRODUCTION}

Forearc system is amongst the most exciting tectonic settings as it reflects the dynamic interaction between subducting and overriding plates along convergent margins [1]. Compared to other tectonic settings, the forearc systems evolution require the action of multiple, time variable driving parameters [2], which include plate convergence rate and direction, slab dip, fluid fluxes, structural complexities and sediment carried along into the subduction zone with the downgoing plate. These parameters affect the thermal structure of the margin and mantle wedge [3],[4] and modify the stress field in the overriding plate [5]-[7]. Reconstructing the tectonic evolution of forearc systems provides an insight of plate interactions over time.

Forearc basins [8]-[11], show that their sediment fill recorded the tectonic history of both the Volcanic Arc Massif and the Outer Structural High [12]. Tectonically, these basins can be developed in two types of margins: accretionary margins erosive margins. For example, the Hikurangi forearc basin is built on an accretionary wedge supported by the down-flexed lower plate [13],[14], whereas the Sandino forearc basin probably developed over a segment of the erosive Nicaragua margin that is supported by the mantle wedge [15]. Interestingly, some active margins have developed double forearc basins [10], which widely reflect the interaction between upper and lower lithospheric plates.

[16],[17] and the offshore Manglares basin [17],[18], which are separated by the Remolino - Río Verde structural high (Figures 1 and 2). The large-scale structural geometry of the forearc system is known from wide-angle seismic and gravity data [19]-[21], whereas the shape of the basins and the thickness of the sediments are constrained by Multi Channel Seismic (MCS) profiles and gravity data [23],[17]. In addition, the Cenozoic chronostratigraphy of each of these basins has been detailed [24]-[26];[17] allowing to reconstruct the deformation history over the entire forearc system. This arrangement of sedimentary basins seems to extend northwards in the area of the Atrato and Choco basins, separated by the Serranía del Baudó (Figure 1).

Some convergent margins, such as the Cascadia [10] and northeast Alaska

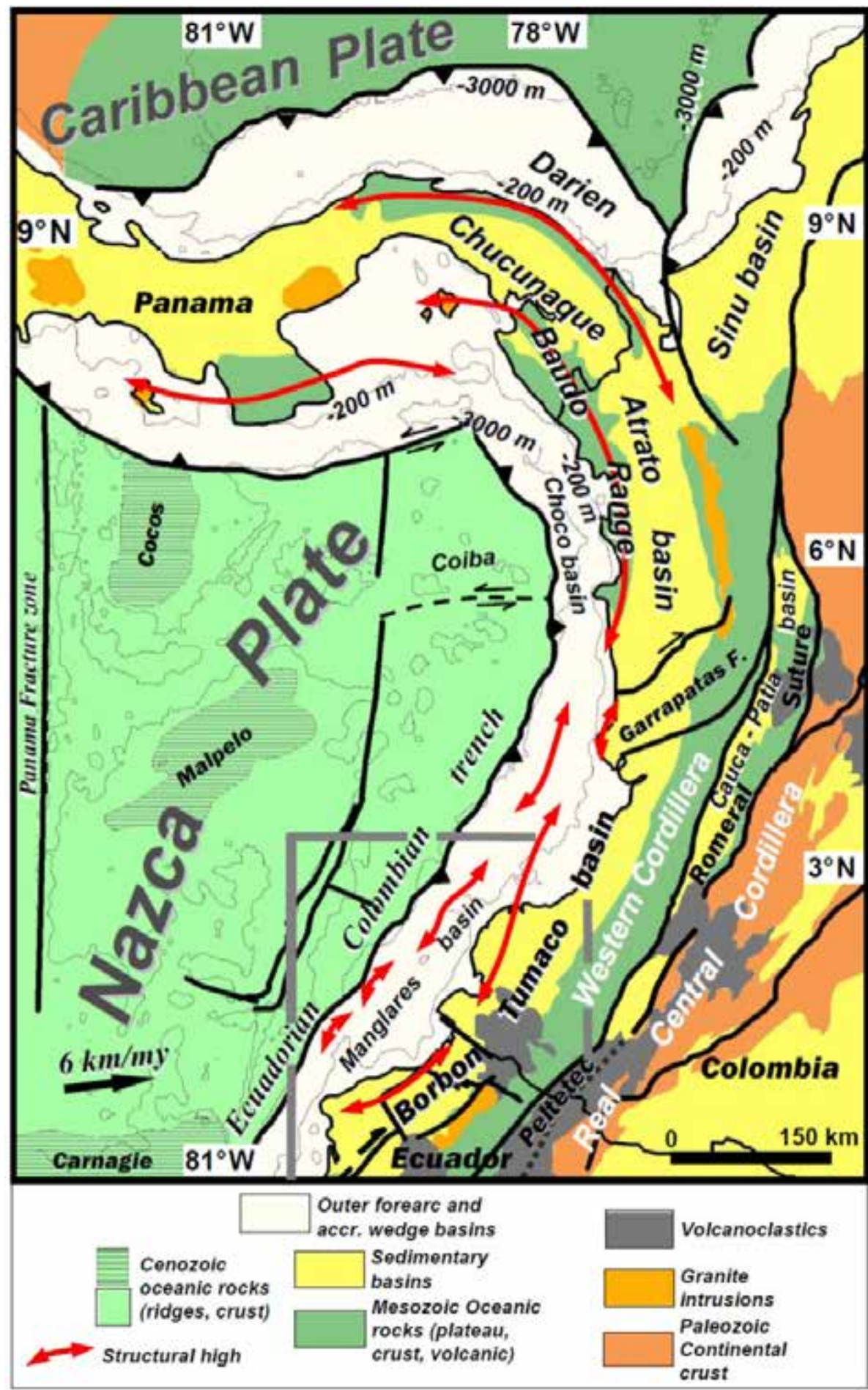

Figure 1. Regional morphostructural units and basins in the northern South America. Thick gray line defines the area of the North Ecuador - South Colombia (NESC) margin. Note the arrangement of the sedimentary basins paired along the forearc zone, like Borbón - Tumaco and Manglares basins, divided by structural highs, and their extension toward the North into the Atrato and Choco basins divided by the Baudó Range. 
[10], show a double forearc basin that is characterized by inner and outer basins divided by an Inner Structural High (Figure 3). In both zones, seismic refraction profiles suggest that the Inner Structural High (ISH) resulted from crustal duplexing [27],[28] and played an important role over the sediment distribution in the basins. The formation of double forearc-basins on continental margins is unusual and the uplift of the ISH is a key process related to the evolution of the basin's geometry, fill and sediment distribution [10]. However, the development of double forearc basins is not fully understood as it implies complex relationships between basins subsidence, and uplift of both the ISH and the landward sources of sediment. Understanding these relationships requires onshore-offshore integrated studies.

In this paper, we reconstruct the Cenozoic evolution of the double forearc basin and tentatively correlate it with plate kinematics and slab dip changes, as well as with the thermal evolution of the upper plate mantle wedge to discuss potential mechanisms responsible for the basin's formation and margin deformation over the last $40 \mathrm{Ma}$. We first integrated individual results of the basin analysis over each of the Tumaco - Borbón and Manglares basins [17] to produce a single chronostratigraphic summary diagram of the whole double forearc basin.

We then identified several isochronal surfaces used to improve the chronostratigraphic correlation between seismic sequences and lithological units, across the forearc region. These surfaces also allowed to define two regional surfaces bounding three megasequences, which reflect regional plate reorganization. Finally, we used facies distribution and structural maps at selected time intervals, and 2D backstripping analysis to visualize the evolution of the margin deformation and depositional environments, prior to discussing possible drive mechanisms

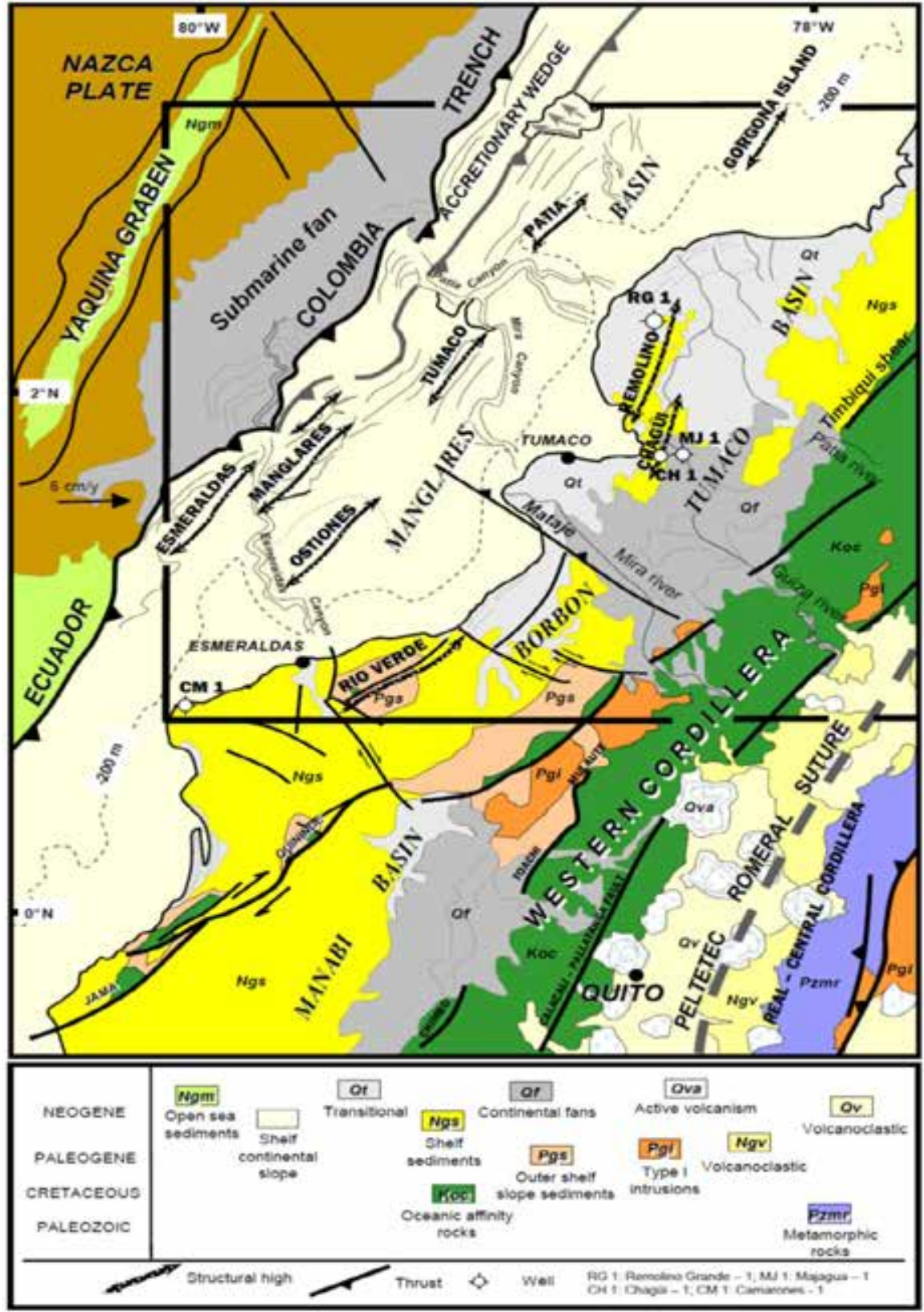

Figure 2. Geological sketch of the NESC margin showing the location of the places mentioned in this work. The dark thick line shows the area when constructed facies distribution maps are at 8 different interval times (Figures 9 to 16) by the integration of outcrop data, geological maps, wells and seismic lines information.

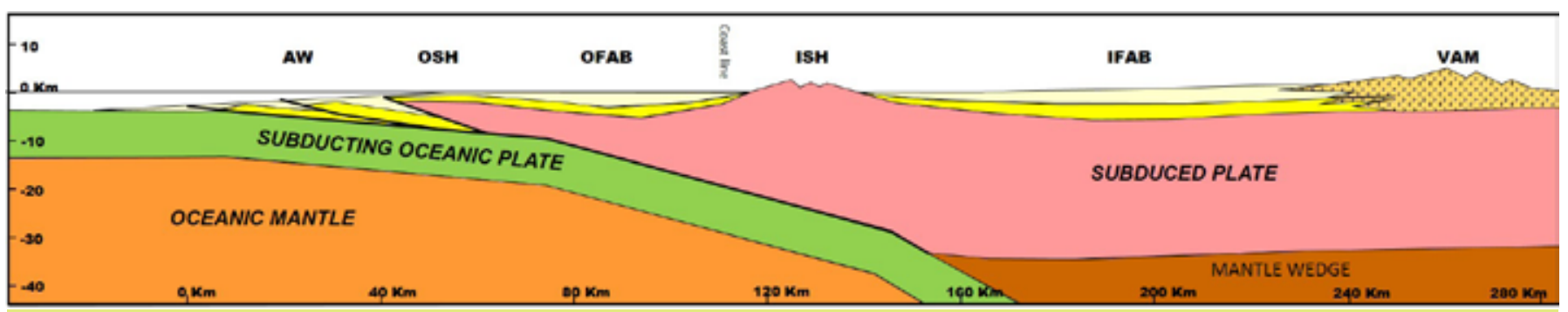

Figure 3. Schematic cross section trough the forearc zone with the development of a double forearc basin system (adapted from Calvert [27] and [10]); . The major boundaries of the forearc basins are defined by the Volcanic Arc Massif (VAM) and the Outer Structural High (OSH), this second controlled by the development of the Accretionary Wedge (AW). The development of the Inner Structural High (ISH) made possible to divide the forearc into the Inner Forearc Basin (IFAB) and the Outer Forearc Basin (OFAB). 
In the NESC margin area, three major tectonosequences can be observed according to their genesis and age. The first tectonosequence is characterized by igneous basic rocks and composed of peridotites, dolerites and gabbros [29]-[34]. According to geochemical and geochronological data [35], they were formed in oceanic plateaus during the Cretaceous (Figure 2). Plateau fragments were accreted between the Late Cretaceous to Paleocene times along the northwestern South America corner [31],[36]-[39].

The second tectonosequence overlying the igneous basement is characterized by volcanic rocks (Figure 2) composed of pillow basalts, andesitic massive lavas, basalts and pyroclastic rocks [31],[33],[34] accumulated between the Late Cretaceous - Early Eocene. The geochemical analysis suggests that the lower part of this group was formed in an island arc tholeiitic setting, while the upper part was formed in a calc-alkaline arc setting [31],[33].
A third tectonosequence covers discordantly the two groups described above and is characterized by sedimentary rocks accumulated during the Cenozoic. Onshore, in the Tumaco-Borbón basins, the base of the third group is composed of calcareous sandstones, radiolarian shales and shales accumulated between the Late Eocene and the Late Oligocene in a deep-marine slope environment of variable depositional energy [30], [40]-[42]. The top of the third tectonosequence is composed of sandy shales, limestones and volcanic materials accumulated in shallow marine and deltaic environments (Figure 2), between the Miocene Holocene [43],[30],[44]. Offshore, the seismic stratigraphic studies allow to extend the third tectonosequence across the whole Manglares basin [18], where sediments accumulated in deepmarine margin slope to deltaic environments [17]. Landward of the forearc basins, the geochronological data suggest that during the Cenozoic, a magmatic and volcanic activity occurred along the Western and Central - Real cordilleras [45],[38],[34].

\section{EXPERIMENTAL DEVELOPMENT}

To construct a chronostratigraphical chart across the northern Tumaco and Manglares basins, we interpreted $-120 \mathrm{~km}$ of seismic reflection profiles (Figures 4 to 7 ), applying the seismic stratigraphic procedure [46],[47]. To identify and date sequences extending in both basins, we integrated the results of seismic stratigraphic and stratigraphical analysis of wells [29],[17] in this chart. Additionally, this chronostratigraphical chart allowed for a regional stratigraphical correlation of the lithological units between onshore outcrops and exploration wells in the Esmeraldas and Tumaco areas (Figure 8). The sequences genetically correlated were grouped in megasequences in the sense of Hubbard [48], where a megasequence correlates with a plate reorganization phase and with a second order sea level fall.

We created a paleo-environmental distribution map for each sequence (Figures 9 to 16) to visualize the evolution of the margin deformation and depositional environments over the last $40 \mathrm{Ma}$. These maps resulted from the integration of 16 selected facies distribution maps of the Tumaco and Manglares basins [17], Lithologies from geological maps [49], [50],[40], [30], biostratigraphic descriptions in more than 80 localities [25],[26],[29];[51],[41], [44],[42], geochronological results [52],[31],[38],[53] and regional geologic interpretations related to the margin evolution [39], [54] - [57]. Based on these bibliographic references, we plotted over each map the biostratigraphic localities (Figure 4), outcrop boundaries of the geological units and the names of the lithostratigraphical units used during our interpretation of various environments.

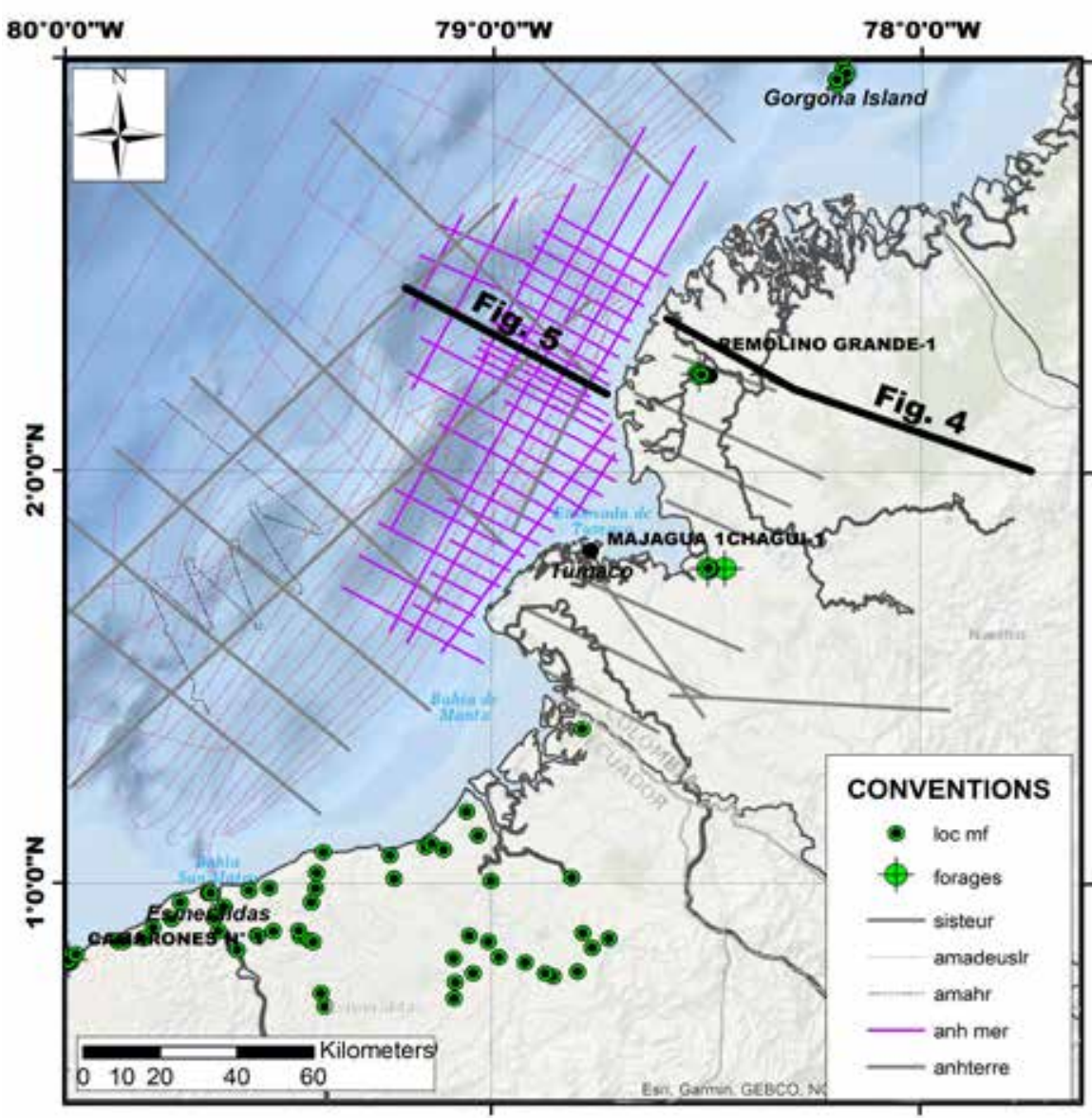

Figure 4. Location map of the seismic reflection profiles (surveys), wells, biostratigraphic localities (loc $\mathrm{mf}$ ) used to build the facies distribution maps. 
This work includes the results of mass balance analysis developed in the Tumaco and Manglares basins and exhumation rates along the NESC margin during the last $40 \mathrm{My}$. The volumes of sediments accumulated in the forearc basins of the NESC margin were calculated using the methodology proposed by Métivier \& Gaudemer [58]. The method needs the creation of depth maps for each top of sequence identified in the basins, in this case with seismic reflection lines controlled with oil exploration wells (Figure 17). Each map becomes a grid (in this study each pixel has $1 \mathrm{~m} \times 1 \mathrm{~m}$ ) and the cumulative mass calculation equation per unit area (described below) is applied to each pixel value:

$$
\mathrm{M}\left(\mathrm{t}_{\mathrm{i}}\right)=\rho_{\mathrm{g}}\left[\left(\mathrm{z}_{\mathrm{i}}+0.43 \times 3014 \times \exp \left(-\mathrm{z}_{\mathrm{i}} / 3014\right)\right)-(0.43 \times 3014)\right]
$$

$M(t i)=$ Mass accumulation per unit area

$\rho g=\quad$ Grain density (average value of $2,7 \times 103 \mathrm{~kg} / \mathrm{m} 3$ by Baldwin \& Butler [99]

zi $=\quad$ Depth in meters.

Finally, the difference between the results of the calculations in each grid will provide the values of the accumulated mass per unit area of each seismic sequence at each point of the basins. These values will allow to calculate the total mass of accumulated sediments, added to the total mass of accumulated sediments, as well as the accumulation rates in each time interval (Table 1 ).
Based on the isopach maps and time to depth converted seismic profiles, we made a $2 \mathrm{D}$ quantitative subsidence analysis using the Airy backstripping method along a section through the northern Tumaco - Manglares basins. During the Airy backstripping process, each layer is progressively decompacted and removed to obtain a paleo-basement geometry. The Airy backstripping method requires the input of the layer thickness, density, porosity, compaction constant, and the paleo-depths and paleo-sea levels. The subsidence can be calculated using the equation proposed by Steckler [59] that is described below. Based on this equation, it is possible to estimate the paleodepth of the basement and the accumulated sediments at each point of the profile.

$$
\mathrm{Y}=\mathrm{S}^{*}\left[\left(\rho_{\mathrm{m}}-\rho_{\mathrm{s}}\right) /\left(\rho_{\mathrm{m}}-\rho_{\mathrm{w}}\right)\right]+\mathrm{W}_{\mathrm{d}}-\Delta_{\mathrm{SL}}\left[\rho_{\mathrm{m}} /\left(\rho_{\mathrm{m}}-\rho_{\mathrm{w}}\right)\right]
$$

\section{Where}

$\mathrm{Y}=\quad$ depth of surface on which sediment is accumulated

$\mathrm{S}=\quad$ total thickness of sediment for each time interval

$\rho \mathrm{m}=$ mantle density

$\rho s=\quad$ sediment density

$\rho w=\quad$ water density

$\mathrm{Wd}=\quad$ water column depth

$\Delta \mathrm{SL}=$ sea level change

Table 1. Volumes of sediments accumulated in the Tumaco and Manglares basin during the last 40 Ma. Values of volume of accumulated sediments (Column of Vol in $\mathrm{Kg} / \mathrm{m} 3$ ) are calculated with the mass calculation equation developed by Métivier \& Gaudemer [58]

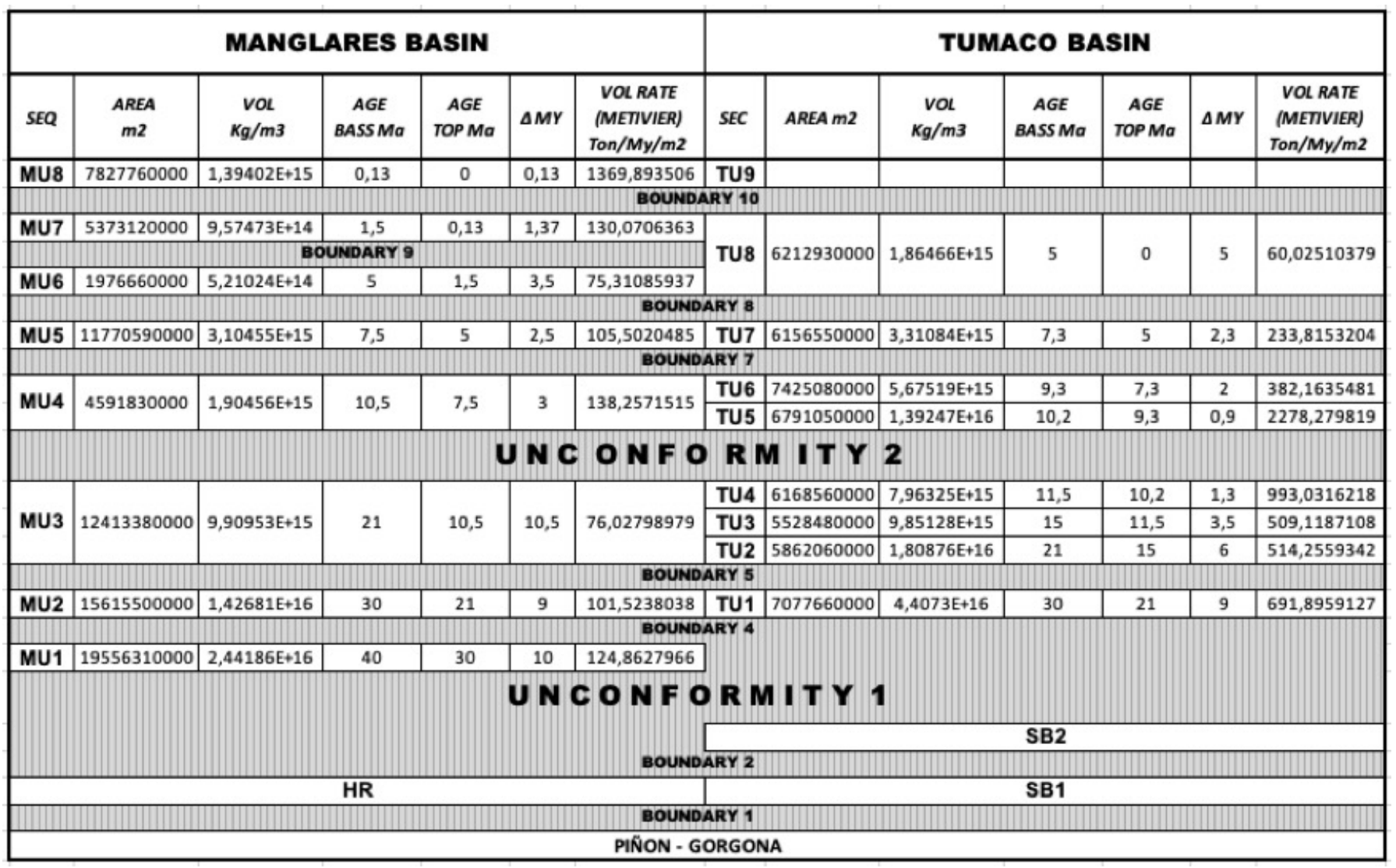


To estimate the decompacted thickness, it is necessary to know: a) the current day thickness of the sediments (in this work the thickness of the sequences was extracted every $5 \mathrm{~km}$ along the regional section of the Figure 5). Additionally, the values of porosity (Фs), compaction constant $(C)$, density $(\rho)$, and grain density were obtained from logs of wells drilled in the Tumaco basin (Figure 18), assuming a sandstone lithology to calculate the porosity from RHOB log according to the methodology described by Rider \& Kennedy [60].

The calibration of the normal shale compaction curve was made by identifiying pure shale intervals (Figure 18), considering the Gamma Ray log values. Paleodepth waters were estimated by micropaleontological data collected from the wells' cuttings and detailed facies analysis [17]. Third order sea level changes are from Haq et al [61] and Westerhold et al. [62]. Backstripping processes begin with the total decompaction of the basal sedimentary unit and its gradual compaction by accumulation of the successive units.

Supposing that the basement units (SB1 and 2) considered are entirely lithified, this may then result in an overestimate amount of ughout the regional section, the history of vertical deformation of the forearc basin was reconstructed at each time interval (Figure 19). Finally, with the aim of explaining the evolution of the NESC margin, and proposing the mechanisms that have controlled its evolution through the Cenozoic, two regional crustal sections were constructed and kinematically restored. The sections were constructed integrating regional geological cartography, regional seismic reflection lines (for the upper $10 \mathrm{~km}$ of the sections), seismic refraction profiles (especially in the accretionary wedge and outer structural high), gravimetric models of the NESC margin, and earthquake location along the subduction plane. In each regional cross-section, the data used in its construction was referenced.

For the kinematical restorations, the distance between the trench to the active volcanic centers at three depicted time intervals was considered. This distance was estimated according to the actual length between the trench and the present day active volcanic center (near to $250 \mathrm{~km}$ of length). The active volcanic center position was defined in each megasequence, based on the geochronological data of several intrusive bodies outcropped along the Central and Western Cordilleras.
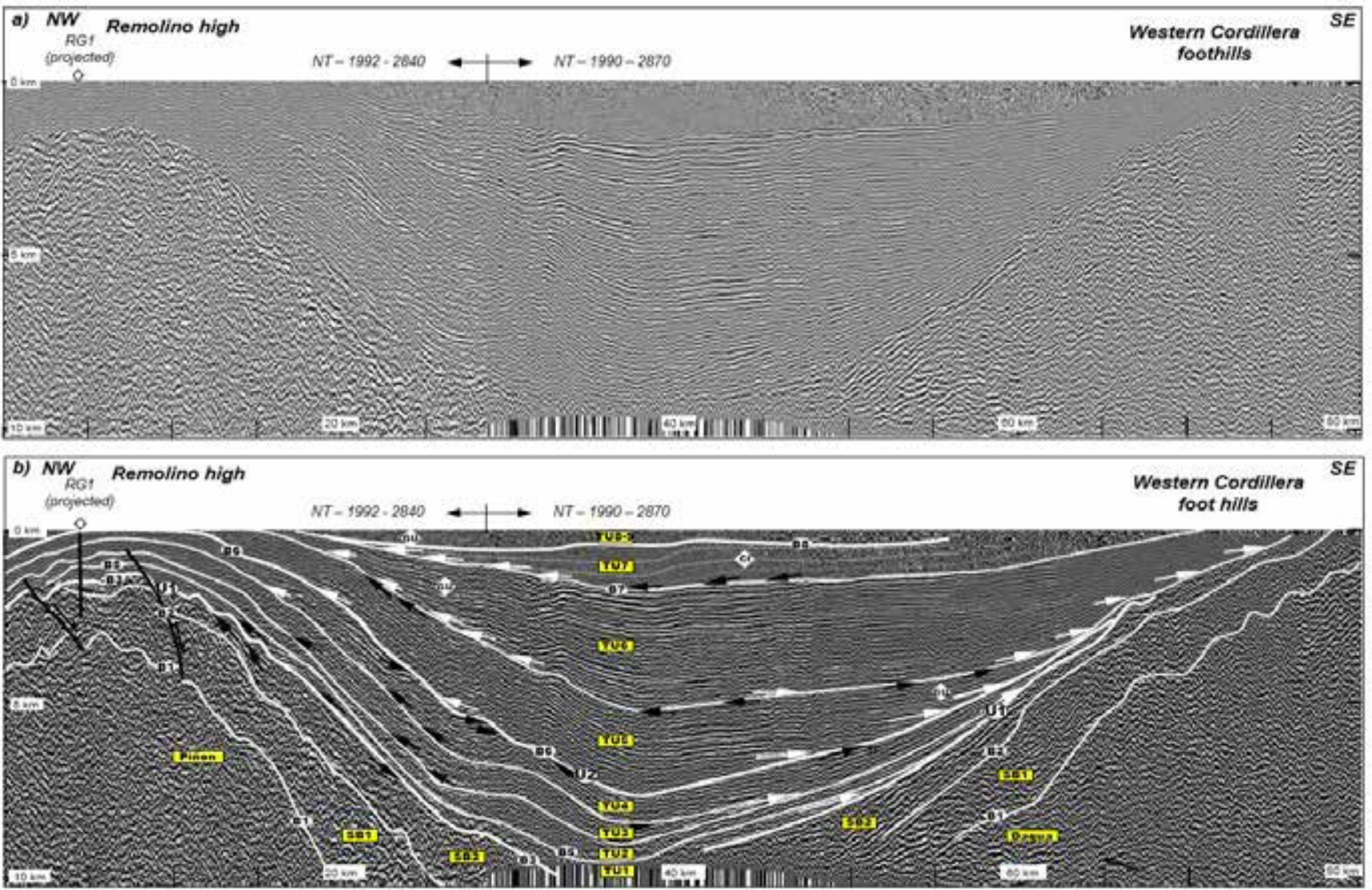

Figure 5. Depth-converted composite seismic line (NT-1992-2840 and 2870) across the northern Tumaco basin (see Fig. 3 for location): a) uninterpreted section; b) interpreted section that shows local and regional seismic sequences boundaries (letters in white circles, labeled B1 to B8 and U1 to U2 respectively), seismic sequences (labeled SB1 and SB2 for basement sequences and TU1 to TU9 for sedimentary sequences in yellow rectangles) and seismic pattern terminations (white arrows to onlaps, black arrows to downlaps, updip black arrows to truncations, white rhombs to zones of growth unconformity, Cf to clinoforms). The interpretation suggests that the Remolino high uplift activity began after accumulation of the TU3 and allowed to develop growth unconformities and onlap surfaces. 


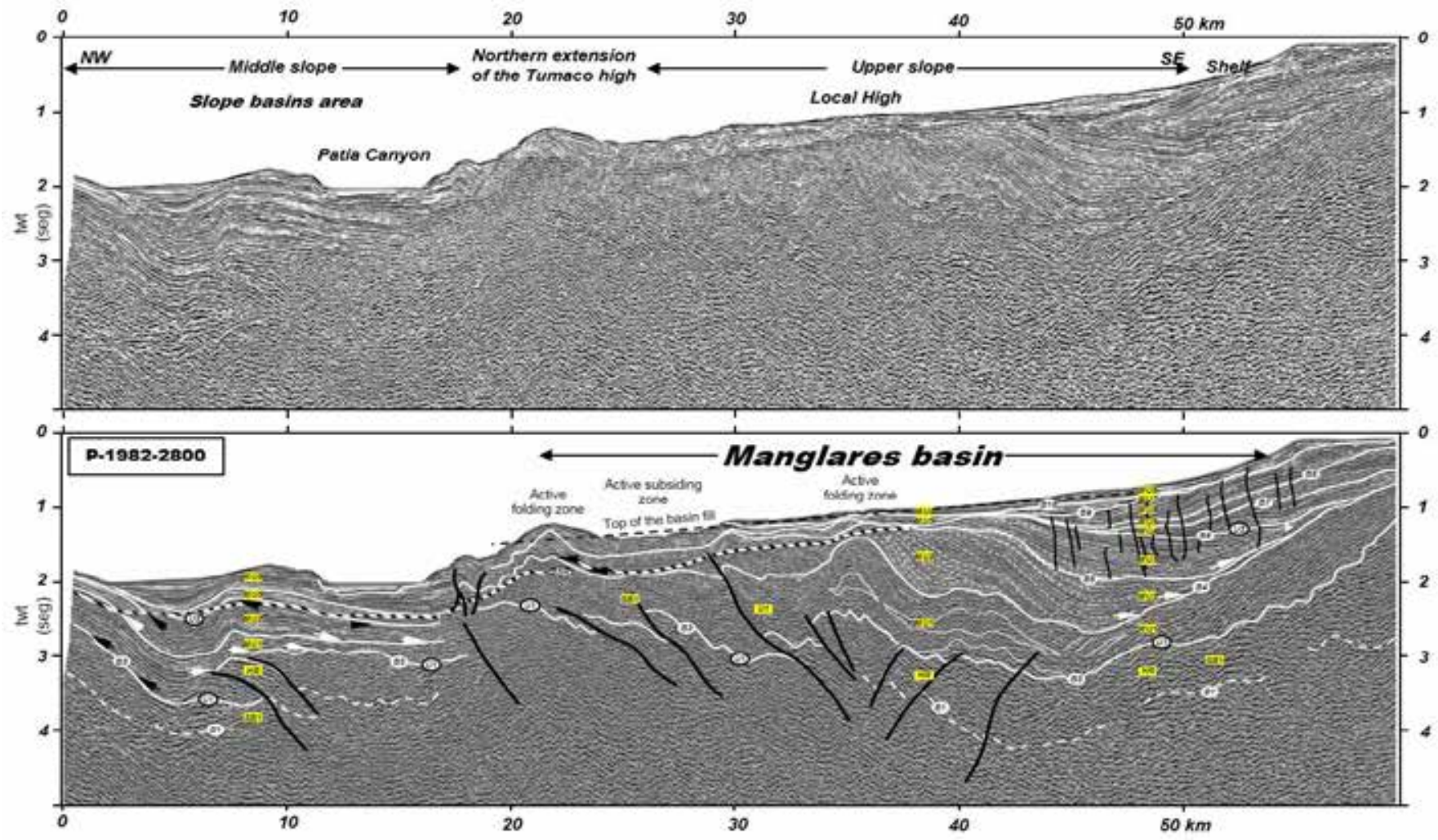

Figure 6. Uninterpreted (above) and interpreted (below) multichannel seismic reflection profile (P-1982-2800) that shows local and regional seismic sequences boundaries (letters in white circles, labeled B1 to B10 and U1 to U2 respectively) seismic sequences (labeled SB1 basement sequence and MU1 to MU8 for sedimentary sequences in yellow rectangles) and seismic pattern terminations (white arrows to onlaps, black arrows to downlaps, updip black arrows to truncations). The HR label corresponds to the zone of High Reflectivity defined by Collot [22]. Thick white dotted line shows the position of the Bottom Simulated Reflector (BSR). The section suggests eastward steeping deformation from the Tumaco high and the development of onlap (white arrows), truncation (updip black arrows) and downlap (black arrows) patterns near the structure. The slightly folding of the upper seismic sequences (MU7 and MU8) made it possible to define two zones of active folding and a small zone of active subsidence between them. Landward border onlapping of the seismic sequences suggests its gradual uplift.

\section{RESULTS ANALYSIS}

According to the stratigraphic correlation in the area, eleven sequences bounded between them by ten seismic sequences boundaries were identified across the Tumaco - Borbón and the Manglares basins (Figures 5 to 8 ). Two of these boundary surfaces (U1 and U2 in Figures 7 and 8 ) were recognized across the northwestern corner of South America [63];[57] and, therefore, represent regional unconformities that bound three megasequences of regional extent. The age of the regional unconformities coincides with the occurrence of global sea level fall events [61]. Because sequences SB1 and SB2 belong to the margin basement, and SB2 is topped by regional unconformity U1, we grouped SB1 and SB2 into basal Megasequence 1 (Figures 7 and 8). Seismic sequences TU1 to TU9 in the Tumaco basin and MU1 to MU 8 in the Manglares basin are Eocene to Holocene sedimentary units acc umulated over Megasequence 1 (Figures 7 and 8). Regional unconformities U1 and U2 allowed grouping sequences TU1 to TU4 in the Tumaco basin and MU1 to MU3 in the Manglares basin in Megasequence 2 (Figures 7 and 8). Sequences TU5 to TU9 in the Tumaco basin and MU4 to MU8 in the Manglares basin were grouped in Megasequence 3 (Figures 7 and 8).

\section{MEGASEQUENCE 1 (SEISMIC SEQUENCES SB1 - SB2)}

Sequence SB1 consists of Late Cretaceous (Figures 7 and 8 ), igneous oceanic rocks, formed over an oceanic plateau setting [31];[32]. In the Manglares basin, wide-angle seismic data suggest that the SB1 is composed of discontinuous low-frequency reflectors with high reflectivity that show 4 to $5 \mathrm{~km} / \mathrm{s}$ Vp velocities at the base of the sequence, decreasing up to $3 \mathrm{~km} / \mathrm{s}$ at the top of the sequence (Figs. 6 and 8). The vertical variations of $\mathrm{Vp}$ velocities are comparable with those of the upper oceanic crust, topped by sediments and volcanic rocks interbeddings [18]. Sequence SB2 covers unconformably SB1 rocks (Figure 5) and is composed of Palaeocene - Early Eocene (Figures 7 and 8), volcanic and volcanoclastic rocks [64],[30],[31], [17],[65],[33];[34]. The geochronological data suggest that along the western border of the Central Cordillera and Western Cordillera there is regional volcano - magmatic activity, contemporary with the SB2 formation [52],[54], [66]. 


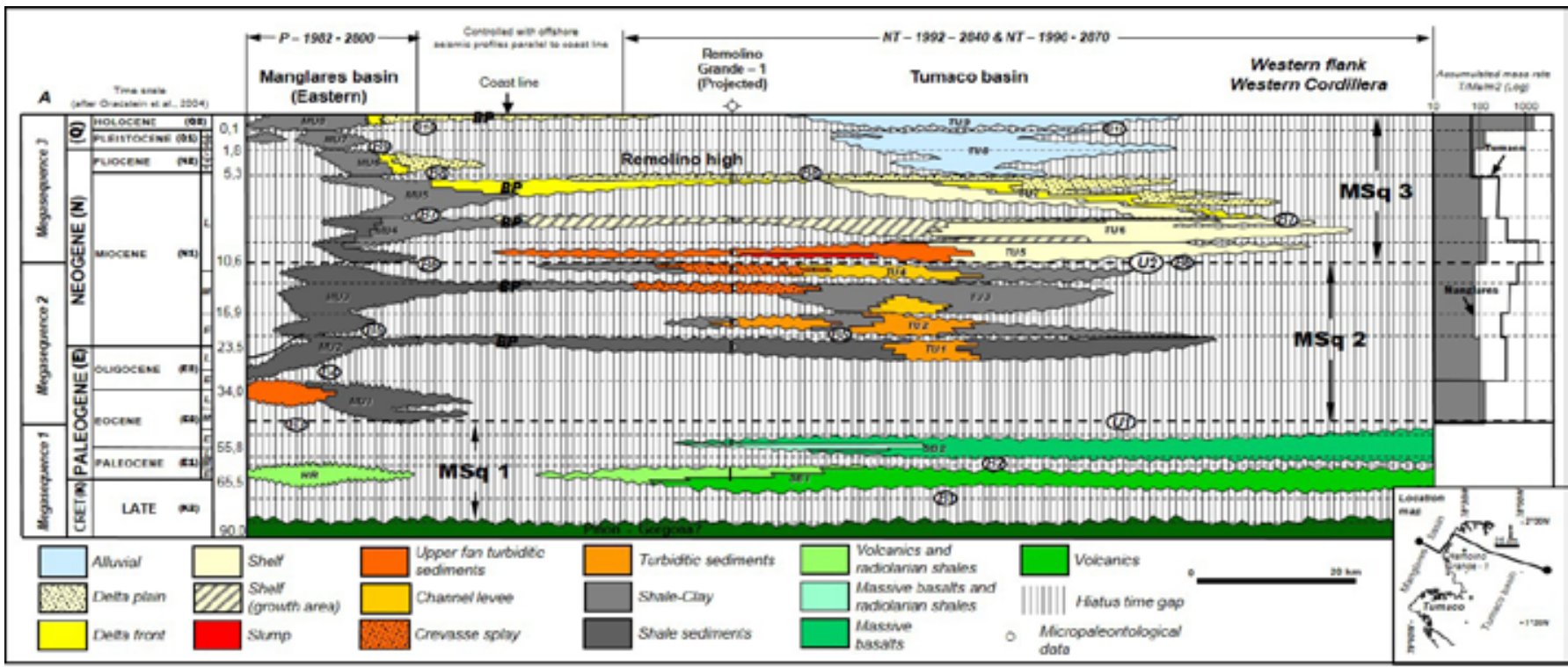

Figure 7. Chronostratigraphical chart through the Manglares and Tumaco basin axis based on seismic facies interpretation of seismic reflection profiles tied with wells ([17]; Borrero et al., 2018). SB1 and SB2 correspond to the volcano sedimentary sequences (see Remolino Grande - 1 in the Fig. 7 for more datails); HR: High reflection zone (See Fig. 5); TU1 to TU9 correspond to the sedimentary units identified in the Tumaco basin; MU1 to MU8 correspond to the seismic units identified in the Manglares basin Circle with U correspond to regional unconformities and circle with B to local unconformities. MSq 1 to 3 correspond to regional megasequences of third order. During overfilled basin times, bypass (BP) conditions were developed between landward to seaward basin. Sequences (basinal extension) and megasequences (regional extension) recognized along the northwestern Ecuador and southwestern Colombia area during this study are defined in the column A. Accumulated mass rates in the Tumaco and Manglares basins according to López [17].

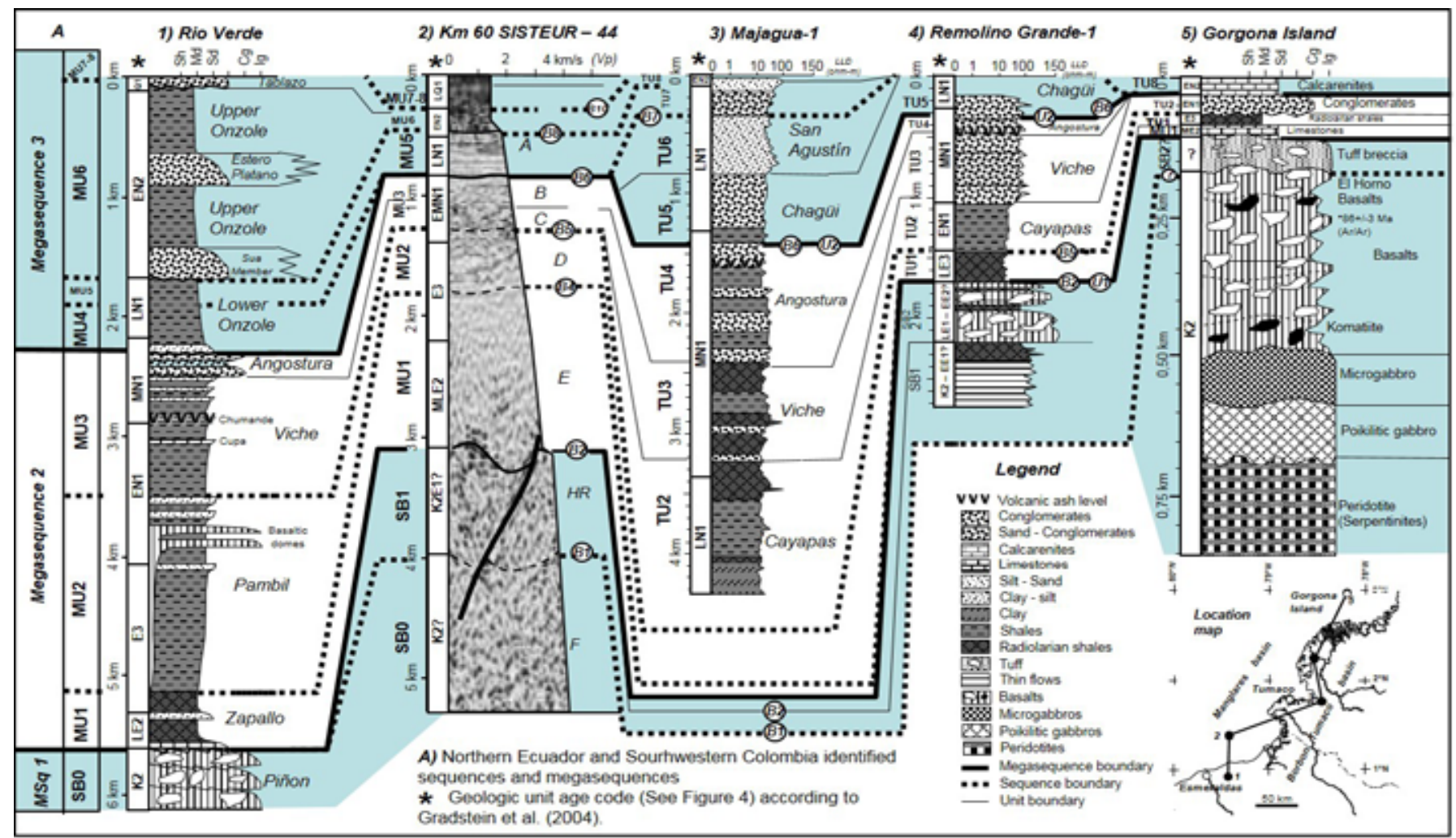

Figure 8. Stratigraphic correlation between lithological units defined in the Esmeraldas and Tumaco areas and seismic units defined in the Manglares basin (See numbers in the location map for position of the stratigraphic columns). Thick letters at left of each column correspond to the regional identified sequence in this work (MU: Manglares seismic Unit; TU: Tumaco seismic Unit; SB: Seismic sequence into the Basement; HR: High Reflectivity zone; F: Bas of the High Reflectivity zone) and to the right of each column the identified seismic unit or lithostratigraphic formation. Letters with circles correspond to sequence boundaries (B: Seismic sequence; U Regional Unconformities). Sources: Column 1 according to Cantalamessa [43], [40] and Ordoñez [44]; column 2 according to Collot [22]; columns 3 and 4 by Borrero [29] and López [17]; column 5 reconstructed from Echeverría [64] and Sinton et al. (1993). Gelogic time scale according to Gradstein \& Ogg [95] 


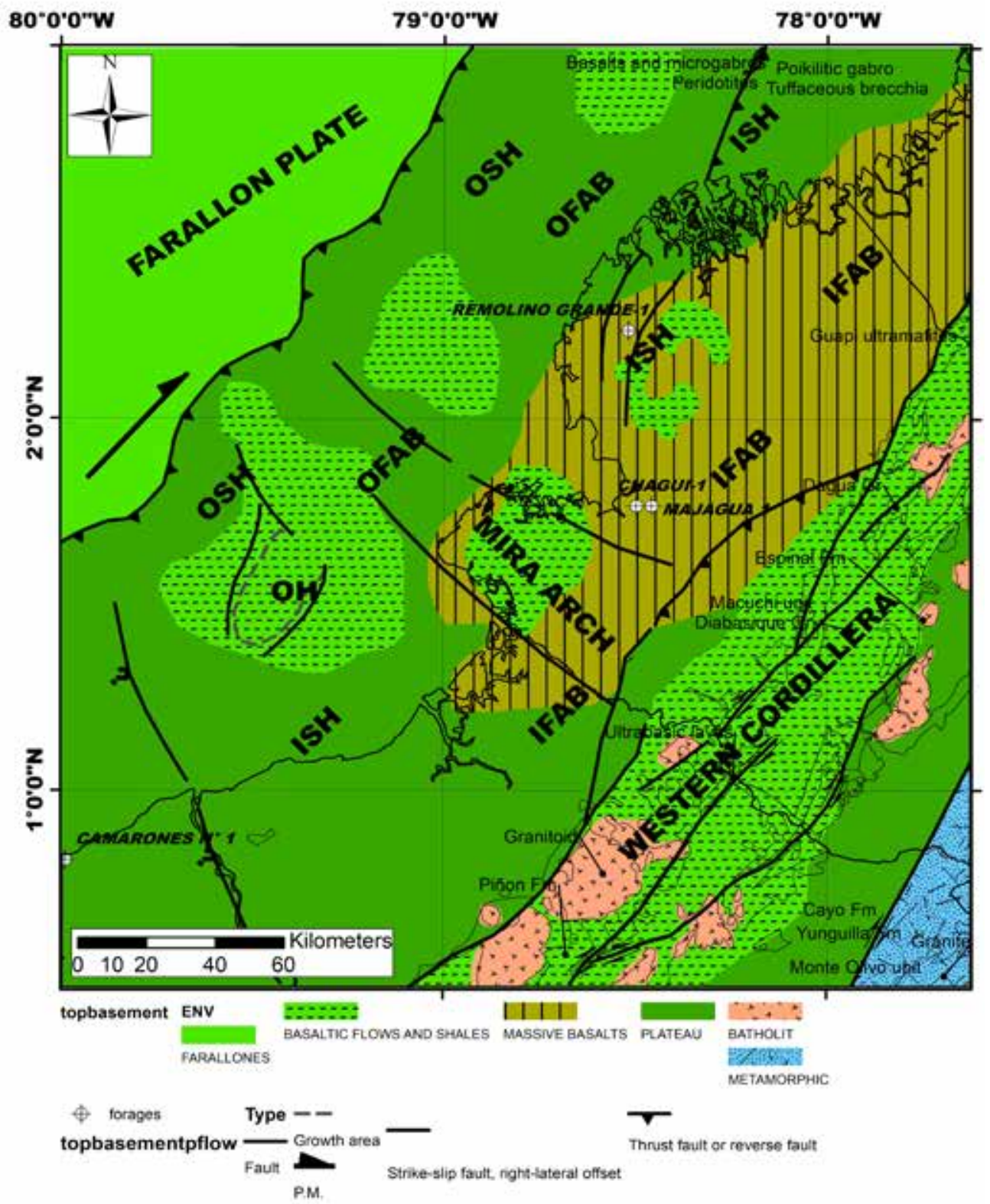

Figure 9. Sedimentary facies and tectonic setting map of the NESC margin between SB1 and SB2. The map depicts a paleoenvironmental interpretation at the top of the basin basement and active structures: OH=Ostiones high. P.M.: Plate motion vector. This map and subsequent maps have been drawn using present day geographical positions.

The paleo-environmental map at $>40$ Ma shows that volcanic centers occurred close to the present-day Western Cordillera foothills, while westward - in the forearc zone - isolated volcanic centers occurred near the transverse Mira arch, the Ostiones high and in other local areas (Figure 9). Regionally, between Late Cretaceous and Palaeocene northeast trending strike slip movements occurred along the Western Cordillera [67] while block rotation deformed the forearc zone [68] during highly oblique convergence of the Farallon Plate [69]. It is likely that during the Late Cretaceous to Palaeocene, the distribution of the volcanic activity and structures (Mira arch, Ostiones high) on the NESC margin was controlled by regional strike slip tectonics (Figure 9 ).

\section{MEGASEQUENCE 2 (SEISMIC SEQUENCES MU1 - 3 AND TU1 - TU4)}

The forearc basin sedimentation in the NESC margin began with seismic sequence MU1, accumulated between -40 and $30 \mathrm{Ma}$ (Figures 7 and 8) to the West of the Volcanic Arc Massif [38], which was developed over the emerged Western Cordillera [55]. Radiolarian shales, shales, cherts and levels of calcareous sandstones are predominant in sequence MU1 (Figure 8). The distribution of the sedimentary environments and structures during the upper Eocene suggests that the forearc zone was segmented 
transversally, near latitude $2^{\circ} \mathrm{N}$, by the NNW-trending basement Mira arch (Figure 10), which outcropped at the sea floor [17]. North of this structure, predominant hemipelagic to pelagic environments and patches of slope fan turbidites were associated with the uplift of the Tumaco and Patia highs, while northeastwards, the submarine volcanic basement was outcropped at the sea floor (Figures 5 and 10). South of the Mira arch, the shallow marine shelf environments that occurred along the Western Cordillera foothills, evolved westward to hemipelagic and locally pelagic environments, with patches of slope fan turbidites of the MUl sequence [40]. These patches were associated with minor uplift areas (Figure 10).
The accumulated mass rates at this time show values near to 200 Tons $/ \mathrm{My} / \mathrm{m}^{2}$ in the Manglares basin, while landward, in the Tumaco basin, the mass rate values are near 0 (Table 1 ). The absence of sediments in the Tumaco basin during this period suggests that most of the sediments derived from the erosion of the landward border crossed entirely the Tumaco area and were accumulated directly over the Manglares basin (Figures 7, 10 and 19). The overall distribution of the sedimentary environments and accumulated mass rates of sequences MU1 indicate that south of the Mira arch, - the forearc zone - was relatively stable, whereas along its north seaward border, the structural highs were tectonically active catching the sediments derived from the landward border.

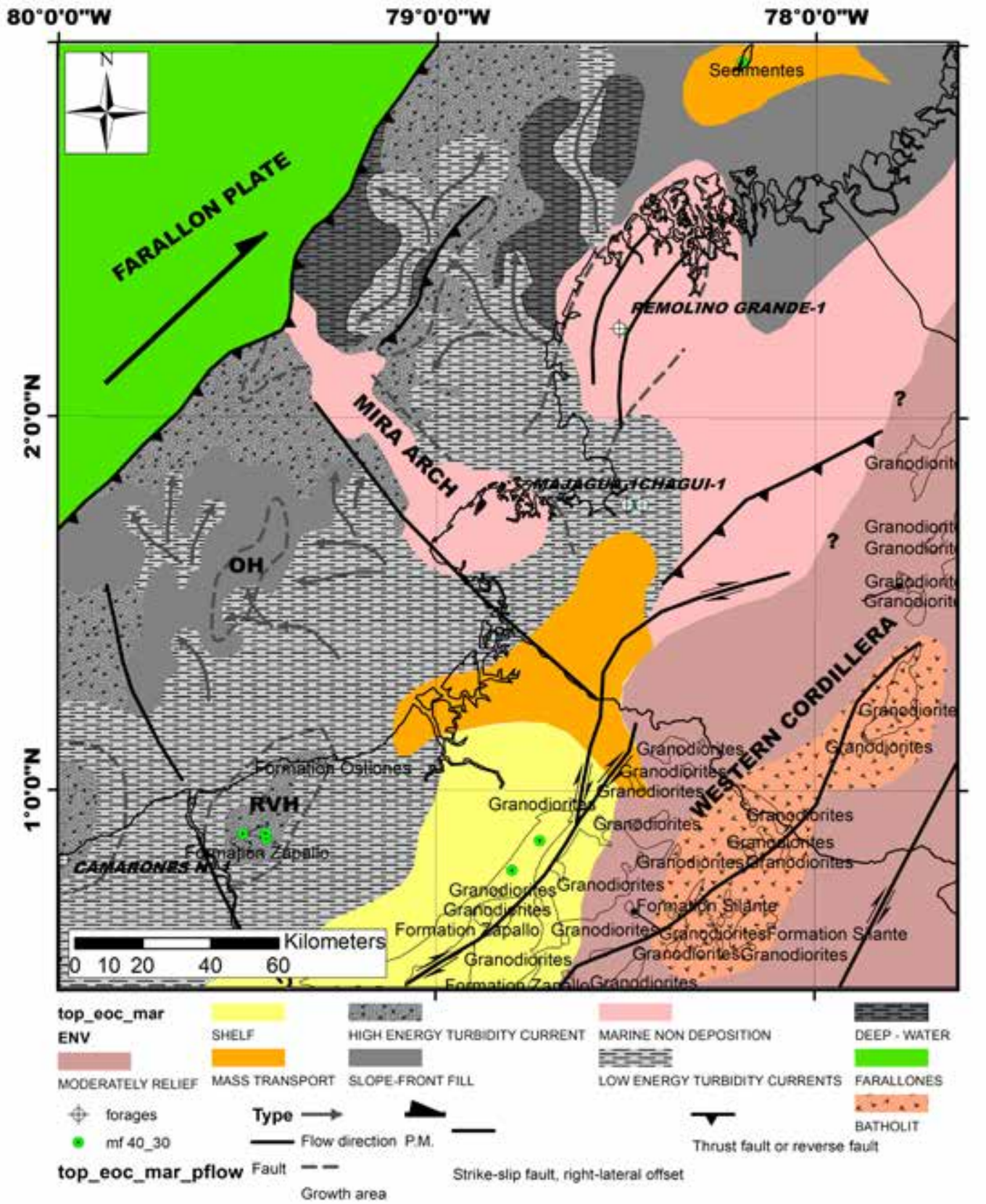

Figure 10. Sedimentary facies and tectonic setting map of the NESC margin of the MU1 sequence (40 - $30 \mathrm{Ma})$. OH=Ostiones high; RVH=Río Verde high. P.M.: Plate motion vector. mf: Outcrop with biostratigraphic data. 
Between 30 and $21.5 \mathrm{Ma}$, the forearc zone was entirely covered by sediments of sequence MU2 in the Manglares basin and TU1 in the Tumaco basin (Figures 5 to 8 and 11), predominantly composed of shales and radiolarian shales, with local sandy levels in the northern Ecuador area [40];[42]. The control of the Mira arch ceased during this period, but the zone was affected by the transverse Mataje reverse fault (Figure 11) and by the trench parallel Ancon fault [17]. The sediments accumulated in the Northeast of the Mataje fault suggests pelagic environments (Figure 11). Isolated zones of slope fan to fan complex environments, occurred over the Mataje fault and slope fan over the Tumaco and Patia highs [29]:[17]. South of the Mataje fault, the sediments accumulated in shallow marine (including local reef areas) to deltaic environments, changing gradually westward to hemipelagic environments (Figure 11). Landward, in the Western Cordillera the continental volcanic arc remained active [49].

The accumulated mass rates estimated during this period show values close to $100 \mathrm{Tons} / \mathrm{My} / \mathrm{m}^{2}$ in the Manglares basin, while in the Tumaco basin, they increase up to $600 \mathrm{Ton} / \mathrm{My} / \mathrm{m}^{2}$ (Table 1). This

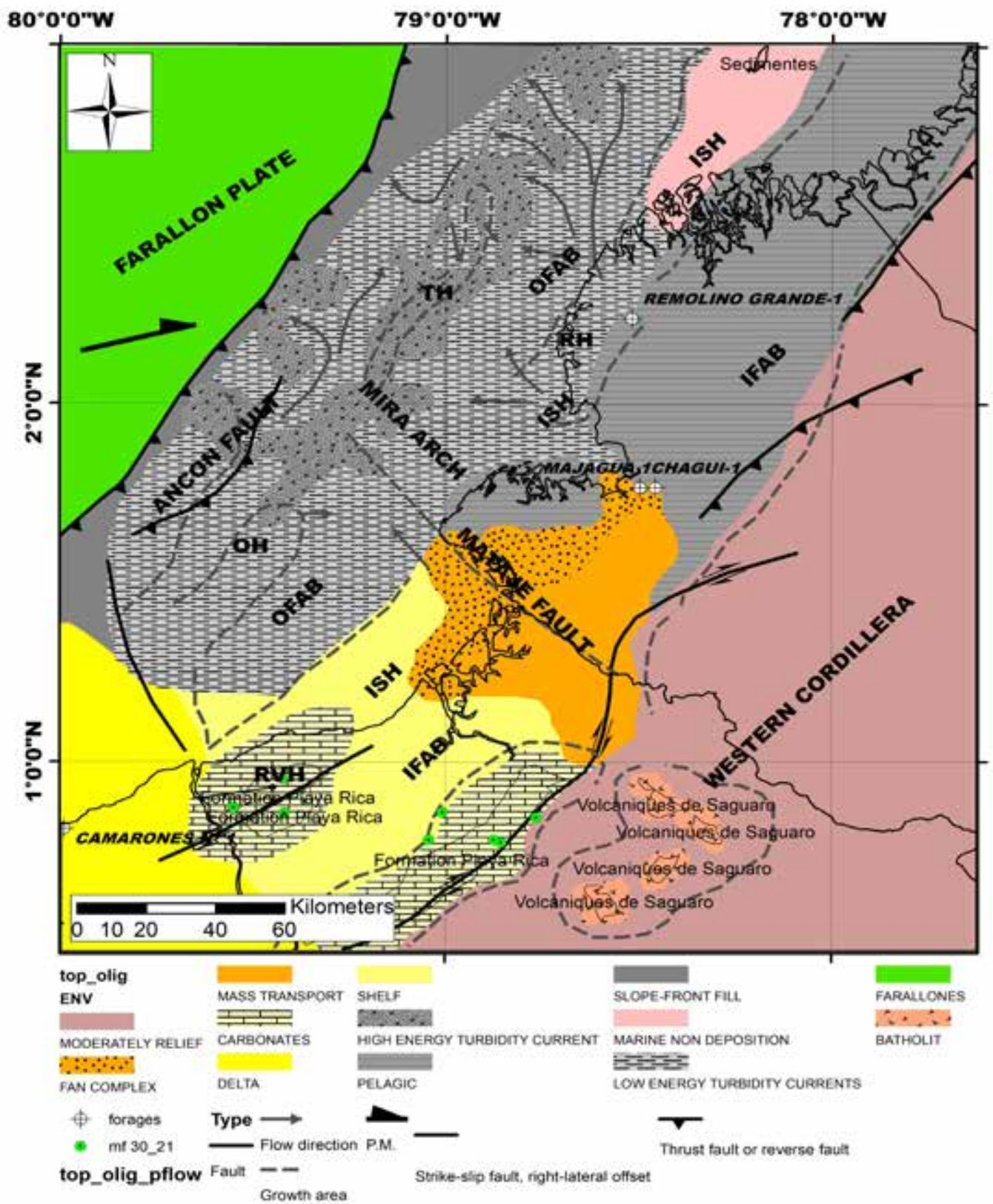

Figure 11. Sedimentary facies and tectonic setting map of the NESC margin of the MU2 - TU1 sequence ( $30-21,5$ Ma). Note the formation of the Inner Structural High (ISH), composed of the $\mathrm{OH}=$ Ostiones high; $\mathrm{GH}=$ Gorgona high; $\mathrm{RH}=$ Remolino high, that divide the forearc zone in the Tumaco Inner Forearc Basin (IFAB) and the Manglares Outer Forearc Basin (OFAB). OH= Ostiones high; RVH= Río Verde high; RH=Remolino high; TH=Tumaco high. mf: outcrop with microplaeontologic data. P.M.: Plate motion vector. 
change in the mass rates suggests that at this time, the Tumaco basin begins its subsidence activity (Inner Forearc Basin), catching a great portion of sediments derived from the landward borders. At the same time, the initial uplift activity of the Rio Verde - Remolino Grande high (Inner Structural High) and the formation of the Manglares basin (Outer Forearc Basin) are registered. The overall distribution of the environments and active structures between 30 and 21.5 Ma support relative stability NE and SW of the Mataje fault, whereas at $\mathrm{N}$ and $\mathrm{S}$ of the fault, the basin seaward border and its structural highs were tectonically active, storing sediments in the landward basin.

Sequences MU3 and TU2-4 accumulated between 21.5 and 10,5 $\mathrm{Ma}$ (Figures 5 to 8 and 12), are composed of shales and calcareous sandstones in the northern Ecuador, while to the north, sequence TU2 is composed of shales that grade upward to conglomerates with high volcanic supply (Figure 8). The conglomerates were formed by erosion of the volcanic arc that had migrated east of the Western Cordillera [17]. During this period, the Remolino - Río Verde structural high increases its uplifted activity (Figures 7, 12 and 19), configuring definitively an Inner Structural High (ISH) and dividing the forearc zone into the Tumaco - Borbón basin to the East (Inner Forearc Basin - IFAB), and the Manglares basin to the West (Outer Forearc Basin - OFAB), thus giving birth to the double forearc basin (Figure 19). The forearc zone, including the structural high, was affected transversally south of latitude $2^{\circ} \mathrm{N}$, by the WNW to NW-trending Manglares and Mataje faults (Figure 12).

Along the Western Cordillera foothills and northern Ecuador, the sedimentation of sequences MU3 and TU2 - 4 occurred in shallow marine shelf environments, while westward, up to the Remolino - Río Verde high, the sedimentation changed to a hemipelagic environment with the development of slope fans - channel levee - fan complex systems rich in volcanic material (Figures 8 and 12). West of the ISH, the accumulation of sediments occurred in pelagic environments, with local development of slope fan and hemipelagic environments over the uplifted Ostiones, Manglares, Tumaco and minor local areas that compose the Outer Structural High (OSH).

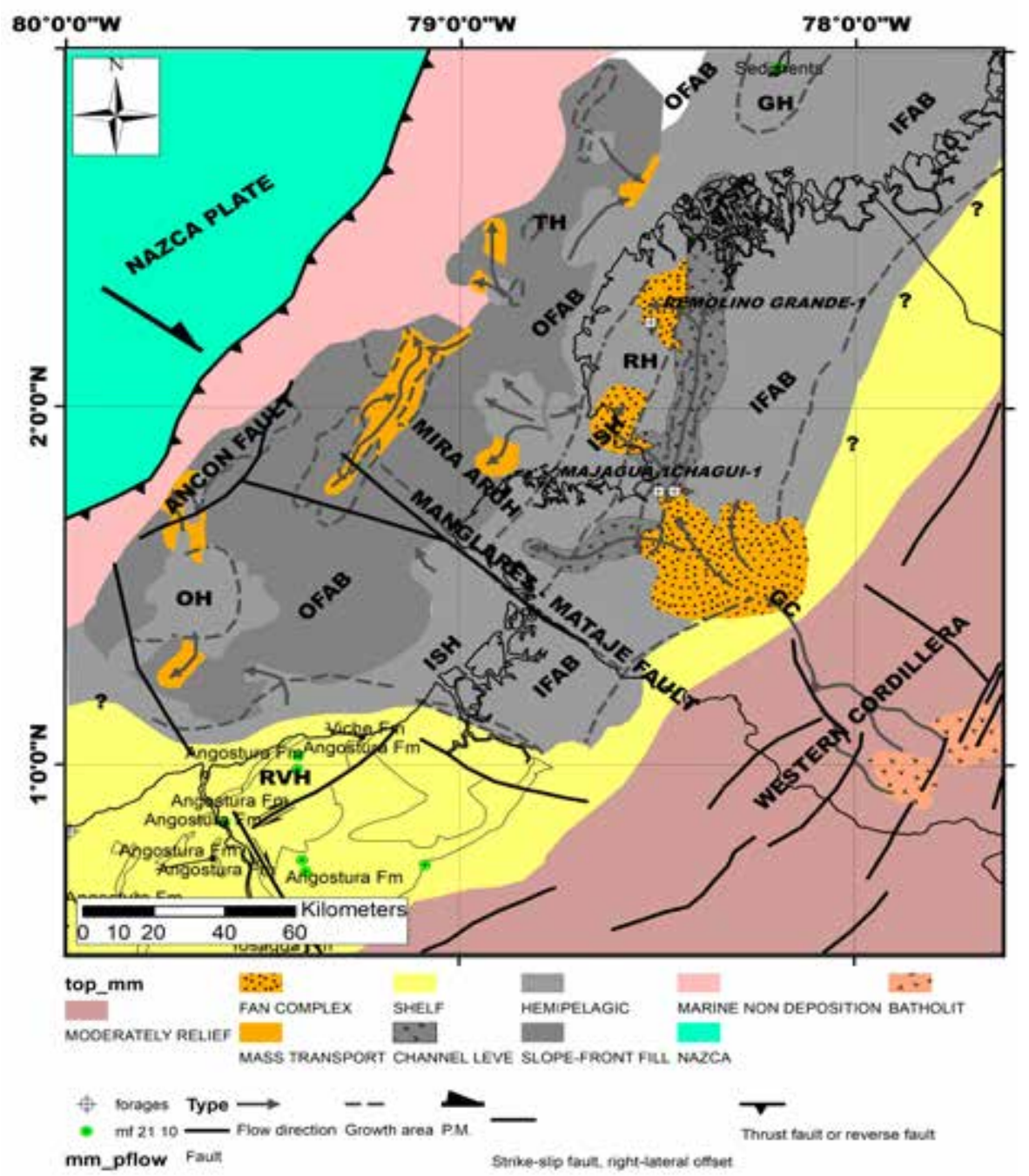

Figure 12. Sedimentary facies and tectonic setting map of the NESC margin of the MU3 - TU2 to 4 sequence $(21,5$ - 10,5$)$. Note the expression of the ISH, composed of the OH=Ostiones high; GH=Gorgona high; $\mathrm{RH}=$ Remolino high, and the IFAB and the OFAB. P.M.: Plate motion vector. mf: outocrop with biostratigraphic data. G.C.: Guiza Canyon. 
It is worth noting that during the deposition of sequence MU3, the accumulated mass rate increased in the Tumaco IFAB relative up to $2000 \mathrm{Ton} / \mathrm{My} / \mathrm{m}^{2}$, while in the Manglares OFAB, the volume of sediments accumulated is close to $80 \mathrm{Ton} / \mathrm{My} / \mathrm{m}^{2}$ (Table 1 ). These contrasting mass rates between both basins reflect the important activity of uplift of the Remolino - Rio Verde ISH at this time. The general distribution of the environments and active structures during the lower and the Middle Miocene indicates that the southern Manglares OFAB and northern Tumaco IFAB subsided, whereas the Borbón IFAB and northern Manglares OFAB basins were relatively stable or affected by minor uplift.

\section{MEGASEQUENCE 3 (SEISMIC SEQUENCES MU4 - 8 AND TU5 - 9 )}

The Seismic Sequences MU4 and TU5-6 represent the first sedimentation after the formation of the double forearc basin.
This sequence accumulated between 10,5 and -7,5 Ma (Figure 7 ), is composed of sandy shales in the Esmeraldas area and conglomerates in the Tumaco basin (Figure 8). During this period, the Western Cordillera, the Remolino - Río Verde ISH, and the OSH of the Manglares basin underwent a generalized uplift, while the transverse Mataje - Manglares faults and the Ancon fault remained active (Figure 13). Shallow marine shelf to delta environments, locally controlled by growth structures, were predominant along the Tumaco - Borbón IFAB. Over the western flank of the Remolino - Río Verde ISH, the sediments that accumulated in hemipelagic and fan complex environments were dammed to the west and south by the Tumaco - Patia OSH and by the Mataje fault (Figure 13). A sedimentation gap in the southern Manglares OFAB during the lower Late Miocene contrasts with large accumulations in the Tumaco IFAB (Figures 8 and 13).

The Tumaco IFAB basin during this period registered high subsidence (Figures 5 and 19), while the Remolino Grande ISH was uplifted and interrupted sediment supply into the Manglares OFAB (Figures

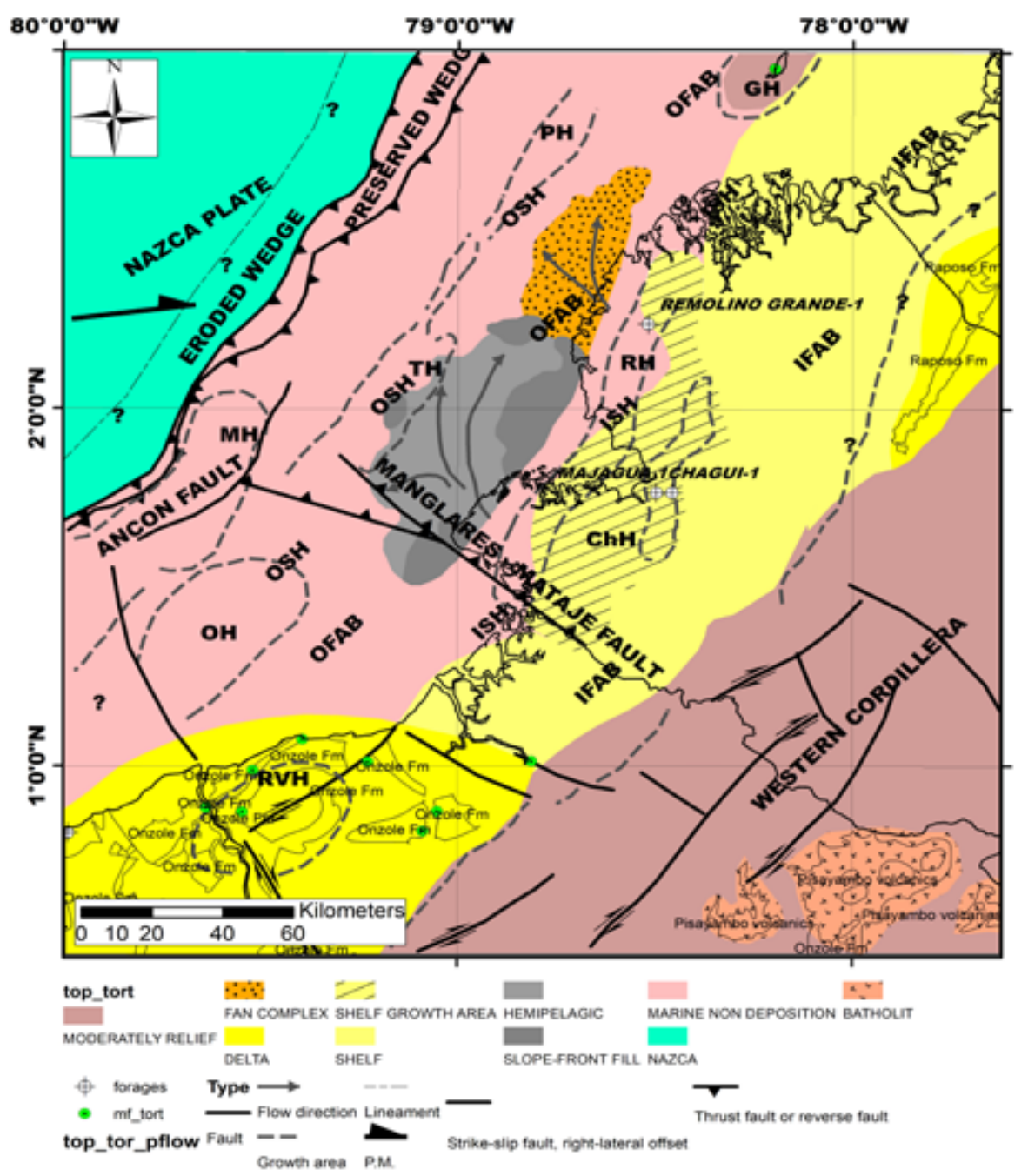

Figure 13. Sedimentary facies and tectonic setting map of the NESC margin of the MU4 - TU5 to 6 sequence (10,5 - 7,5 Ma) During this time, the ISH (composed of the $\mathrm{OH}=$ Ostiones high, $\mathrm{GH}=\mathrm{Gorg}$ ona high, $\mathrm{RH}=$ Remolino high) it is broadly extended toward the North and divide the forearc zone into the IFAB and OFAB. To the West note de expression of the Outer Structural High (OSH), composed of $\mathrm{EH}=$ Esmeraldas high; $\mathrm{OH}=$ Ostiones high; $\mathrm{MH}=$ Manglares high ; $\mathrm{TH}=\mathrm{Tumaco}$ high ; $\mathrm{PH}=\mathrm{Patia}$ high). The Chagüi high $(\mathrm{ChH})$ begin at this time. mf: outocrop with biostratigraphic data. 
5, 8 and 19). Additionally, the large amount of sediments trapped in the Tumaco IFAB basin, which increased to nearly 250 Ton/My/ m2 (Figures 519 and Table 1), favored the shale diapir intrusion, and produced the uplift of the Chagüi high. The distribution of sedimentary environments and active structures during MU4 and TU5-6 sedimentation support strong tectonic deformation in the margin and robust subsidence in the Tumaco IFAB (Figure 19). Although the accumulation mass rates tended to decrease - between $\sim 7,5 \mathrm{Ma}$ to $5 \mathrm{Ma}$, sediment bypassed the Remolino - Remolino Verde ISH towards Manglares OFAB (Figures 5 to 8 and 14).

Seismic Sequences MU5 and TU7 consist of sandy shales in the Borbón IFAB and conglomerates in the Tumaco IFAB (Figure 8).
During MU5 and TU7 accumulation times, the transverse Mataje and Manglares faults were active and several basin highs were slightly uplifted (Figure 14), while subsidence continued in the Tumaco IFAB (Figure 19). The Ancon fault remained active and thrust faults deformed the sea floor west of the Tumaco - Patia highs (Figures 7 , 14 and 19). The paleoenvironmental distribution map of the Seismic Sequences MU5 and TU7 show that the accumulation of sediments occurred predominantly in delta front - shallow marine shelf environments, controlled by the uplift of the Remolino - Río Verde ISH and Chagüi high, while westward, into the Manglares OFAB, hemipelagic to pelagic environments were predominant with local development of slope fans over the Manglares - Mataje tranverse faults (Figure 14). The activity of the faults transverse to the margin triggered slumps from the Remolino - Río Verde ISH. The overall

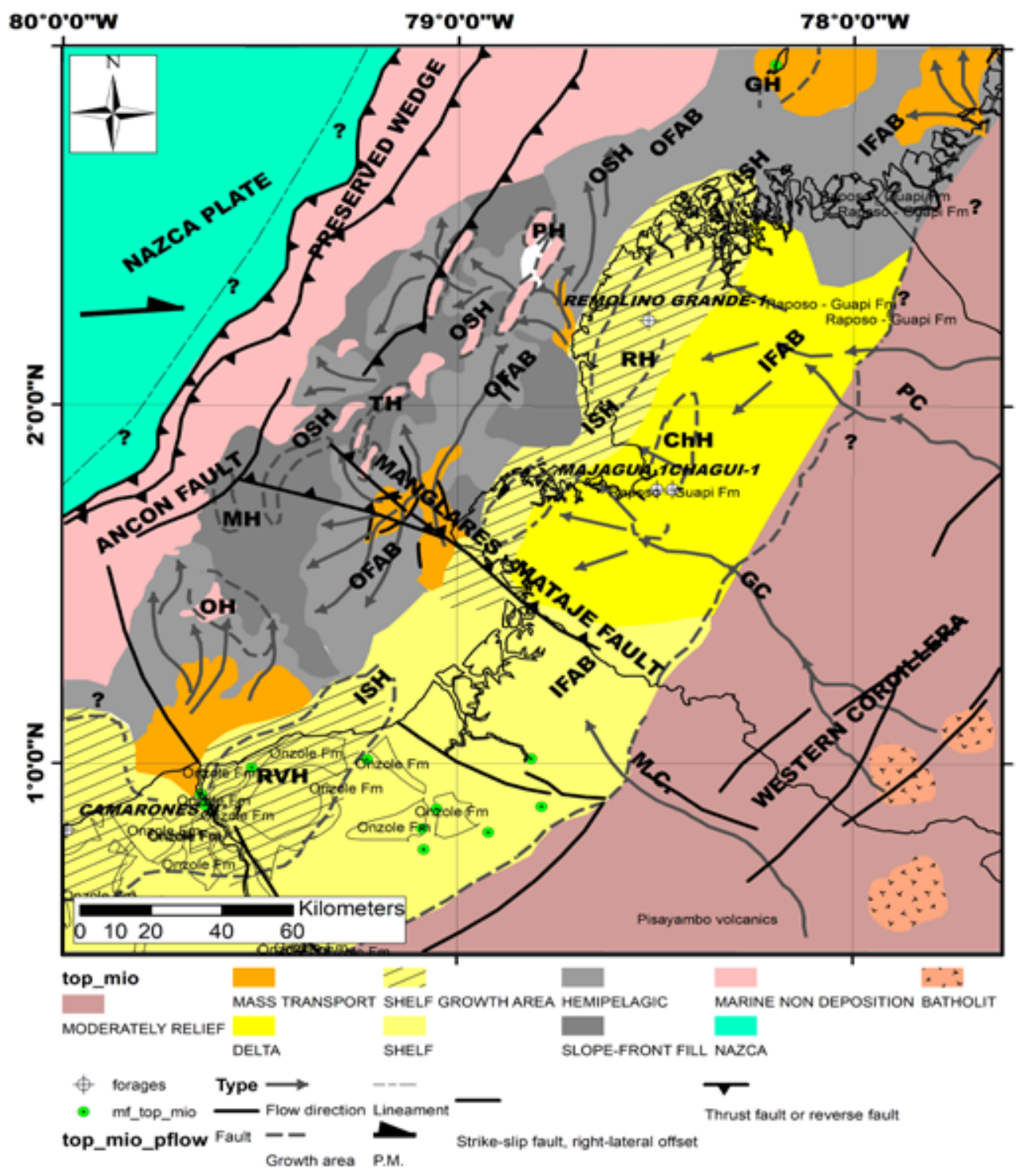

Figure 14. Sedimentary facies and tectonic setting map of the NESC margin of the MU5 - TU7 sequence $(7,5-5 \mathrm{Ma})$. Note the final configuration of the IHS (composed of the $\mathrm{OH}=$ Ostiones high, $\mathrm{GH}=$ Gorgona high, $\mathrm{RH}=\mathrm{Remolino}$ high), OSH (composed of $\mathrm{OH}=$ Ostiones high, $\mathrm{MH}=$ Manglares high $\mathrm{TH}=$ Tumaco high, $\mathrm{PH}=$ Patia high), and the Chagüi high (ChH) related to diapiric uplift Mira canyon (M.C.) carried into the Tumaco IFAB and Manglares OFAB huge volumes of sediments derived from the Western Cordillera. mf: outocrop with biostratigraphic data. 
distribution of TU7 sequence sedimentary environments implies that the Tumaco IFAB subsided during the upper Late Miocene, whereas the Manglares OFAB (Figure 19) were slightly uplifted and Borbón IFAB. Most of the sediment volume was retained in the Tumaco IFAB (230 Ton/Ma/m²), while in the Manglares OFAB half of this volume was retained (Table 1 ), suggesting that the Remolino - Rio Verde ISH had an important uplift activity.

The Seismic Sequences MU6-7 and TU8 accumulated between 5 $\sim 0,1 \mathrm{Ma}$ (Figures 5 to 8 ), are composed of shales and conglomerates in the northern Ecuador, and calcarenites on the Gorgona Island (Figure 8). The margin was deformed simultaneously by the transverse and parallel to trench faults during this period (Figure 15). The paleoenvironmental distribution map suggests that the sedimentation of the Seismic Sequences MU6-7 and TU8 occurred in continental fan to shallow marine shelf environments in the Tumaco IFAB, with sediments transported by the Mira, Güiza and Patia rivers, partially eroded in the Remolino ISH (Figures 5, 7 and 15), while shallow marine shelf to hemipelagic environments extended along the Borbón and Manglares OFAB (Figure 15).

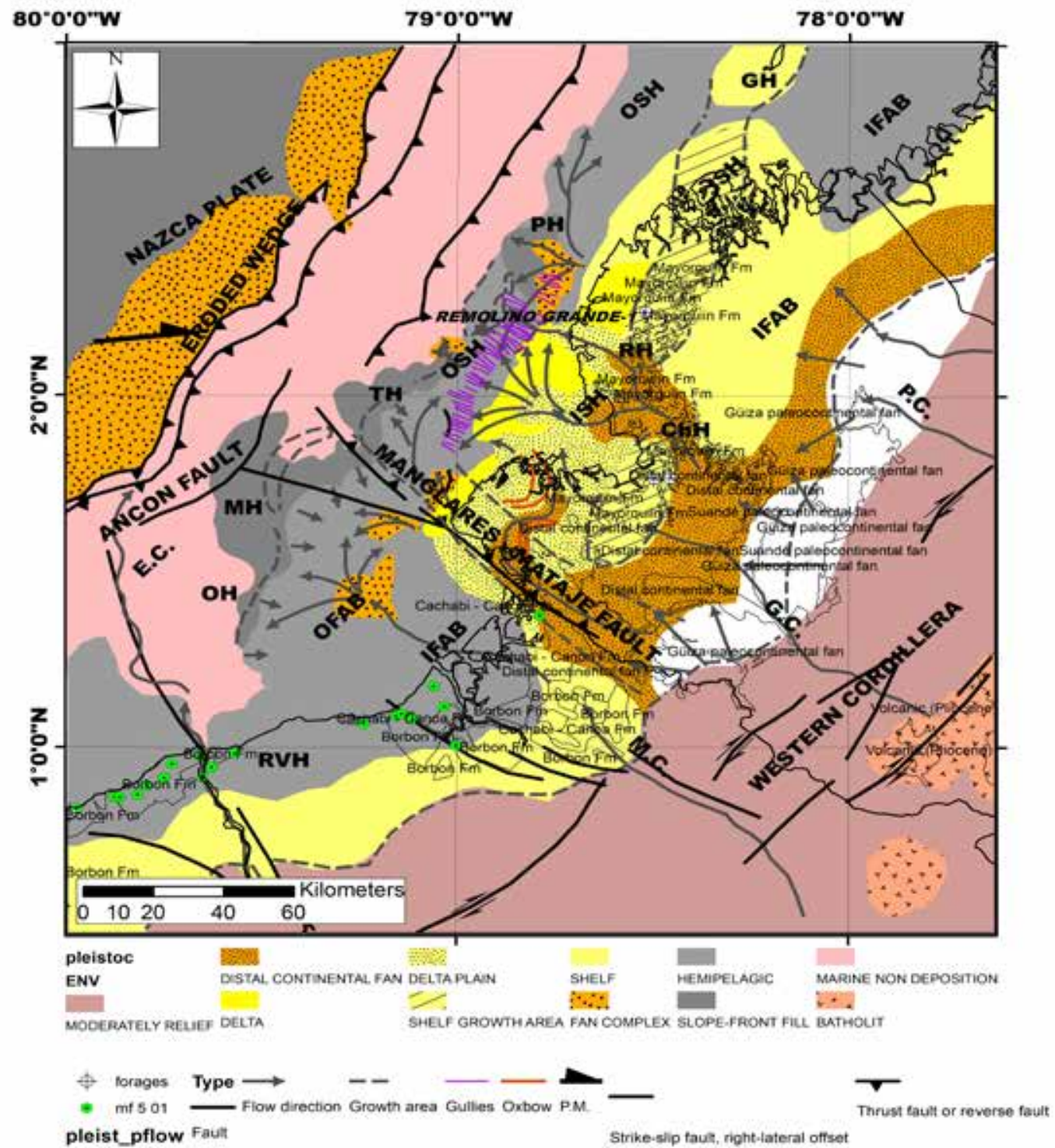

Figure 15. Sedimentary facies and tectonic setting map of the NESC margin of the MU6 to 7 - TU8 sequence ( 5 - 0,1 Ma). Note the distribution of shallow environments at west of the ISH ( $\mathrm{GH}=$ Gorgona high; RH= Remolino high) and intraslope sedimentation retained by the $\mathrm{OSH}(\mathrm{OH}=$ Ostiones high; $\mathrm{MH}=$ Manglares high; $\mathrm{TH}=$ Tumaco high; $\mathrm{PH}=\mathrm{Patia}$ high) in the OFAB, product of huge volume of sediments carried in to the margin by the Mira canyon (M.C.), Guiza canyon (G.C.) and Patía canyon (P. C.). Chagüi High $(\mathrm{ChH})$ affected the distribution of sediments in the IFAB at this time). mf: outocrop with biostratigraphic data. 


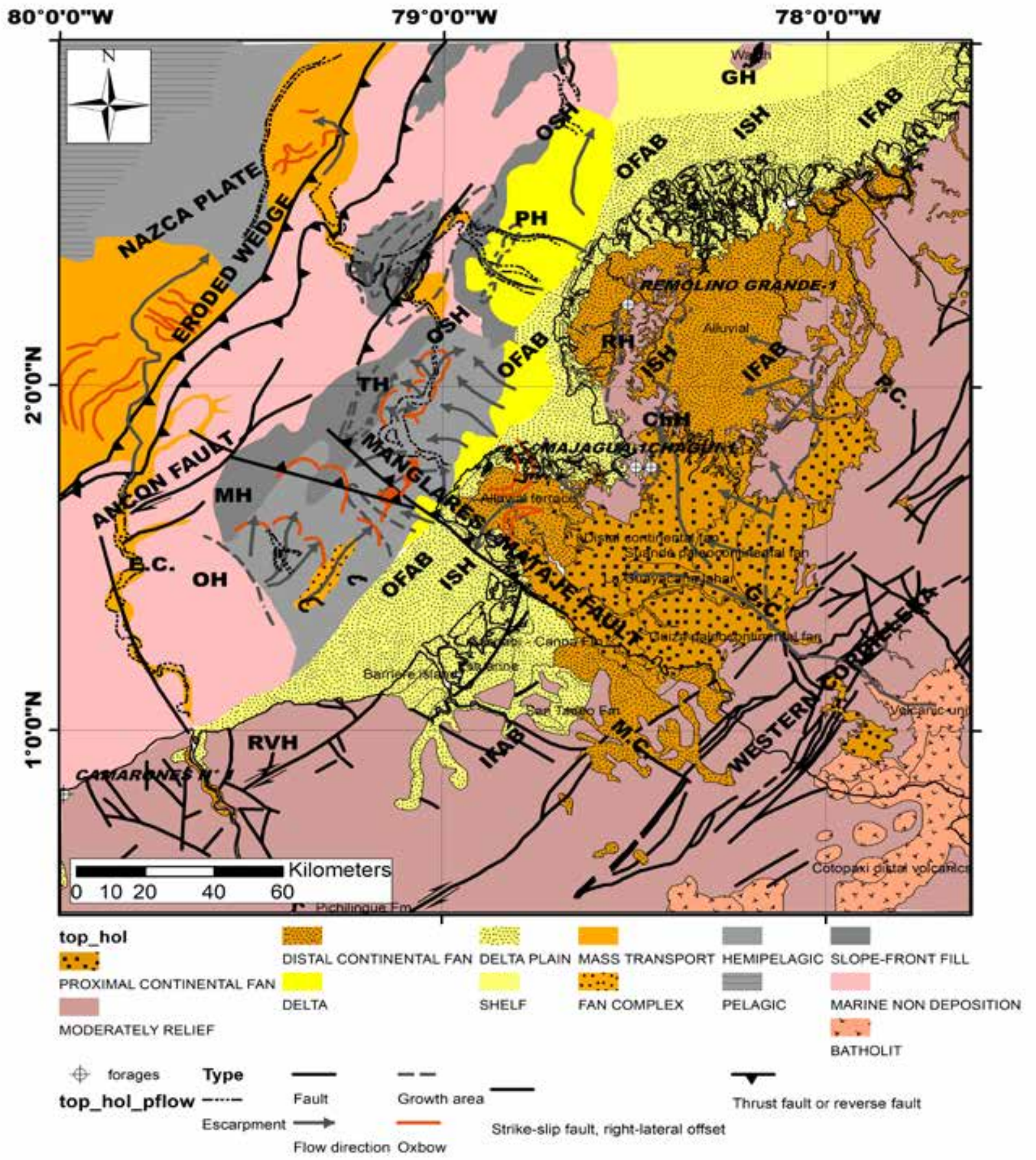

Figure 16. Sedimentary facies and tectonic setting map of the NESC margin of the MU8 - TU9 sequence $(0,1-0,01 \mathrm{Ma})$. Note the distribution of continental fans in the ISH, product of the sediments carried into the basin by the Mira canyon (M. C.), Guiza canyon (G.C.) and Mira canyon (M.C.), while to the South of the Mataje - Manglares fault the sedimentation is predominantly developed in shallow conditions. West of the ISH (RH= Remolino high; RVH= Río Verde high; GH= Gorgona high), the sedimentation along the OFAB is controlled by the OSH activity ( $\mathrm{EH}=$ Esmeraldas high; $\mathrm{OH}=$ Ostiones high; $\mathrm{MH}=\mathrm{Manglares}$ high ; TH= Tumaco high ; PH= Patia high). Submarine margin incision by the Esmeraldas and Patía rivers allow building the Esmeraldas and Patía submarine fans. 


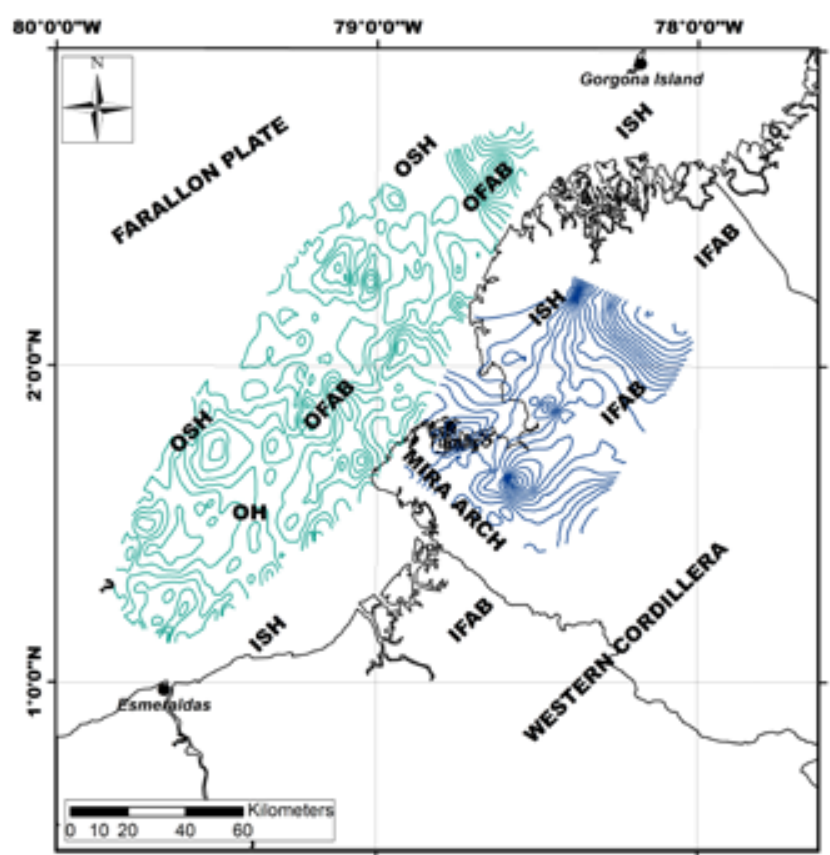

Figure 17. Example of isopach map (contours in meters) of the TU7 seismic sequence in the IFAB and MU5 in the OFAB, divided between them by the ISH and bounded at seaward by the OSH. These types of maps were built for each sequence to calculate the volume of sediments accumulated in both basins during the las $40 \mathrm{Ma}$

The general distribution of environments and structures developed during the Plio-Pleistocene suggests that the Manglares - Mataje faults and Remolino ISH acted as a major boundary between shallow to continental environments in the Tumaco IFAB and northern Manglares OFAB and deeper sedimentary environments in the Borbón IFAM and southern Manglares OFAB (Figure 19). This tectonic activity is consistent with the accumulated mass rates recorded during this period, suggesting that the Tumaco IFAB decreased its catchment activity to nearly $60 \mathrm{Ton} / \mathrm{My} / \mathrm{m}^{2}$, while in the Manglares OFAB it increased up to $200 \mathrm{Ton} / \mathrm{My} / \mathrm{m}^{2}$ (Figure 19 and Table 1).

The Seismic Sequences MU8 and TU9 were accumulated during the last $-0.1 \mathrm{Ma}$ (Figure 7). They were composed of conglomerates in the northern Ecuador area (Figure 8), whilst along the present coastal line of Borbón and Tumaco areas, they contained sandy shales and mudstones [69],[70]. During this period, all basin highs underwent uplift and the transverse and trench-parallel faults were activated. The paleoenvironmental distribution map of Sequence S9 shows that continental fan environments were concentrated in the Tumaco IFAB, while delta to shallow marine shelf environments were developed along the western flank of the Remolino - Río Verde ISH (Figure 16). It also shows that towards the Manglares OFAB, the sediments were accumulated in hemipelagic to pelagic environments.

During sequence Seismic Sequences MU8 and TU9 deposition, large amounts of sediments were probably caught into the slope (Figure 16) and the trench, contributing to the development of the Esmeraldas and Patia submarine fans (Figure 16). The overall distribution of the Seismic Sequences MU8 and TU9 sedimentary environments, and the structures in the margin supports that the sedimentation was strongly controlled by the tectonic activity during

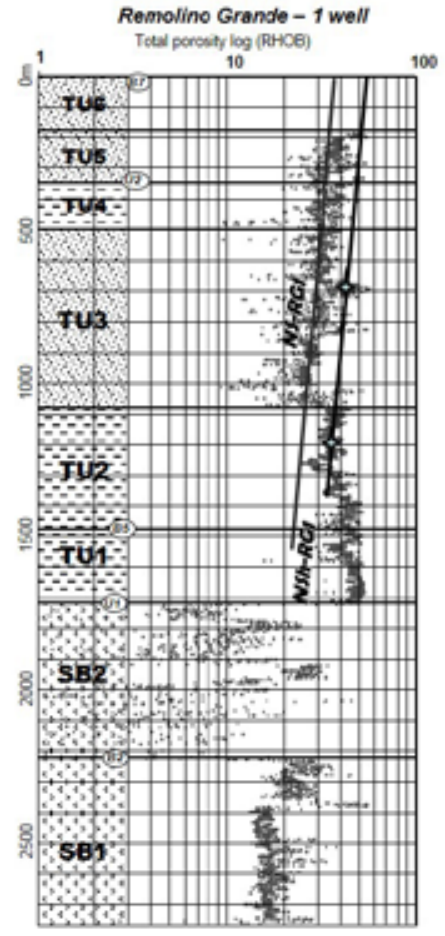

Parameters of the exponential relation between porosity and depth for normal pressured lithologies in the basin \begin{tabular}{ll}
\hline Remolino Grende -1 woll & Majagua -1 well \\
S-RGT Sand compacton & S.Mir Sand compact
\end{tabular}

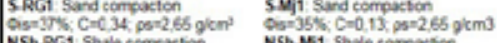

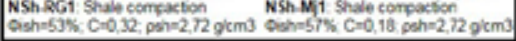
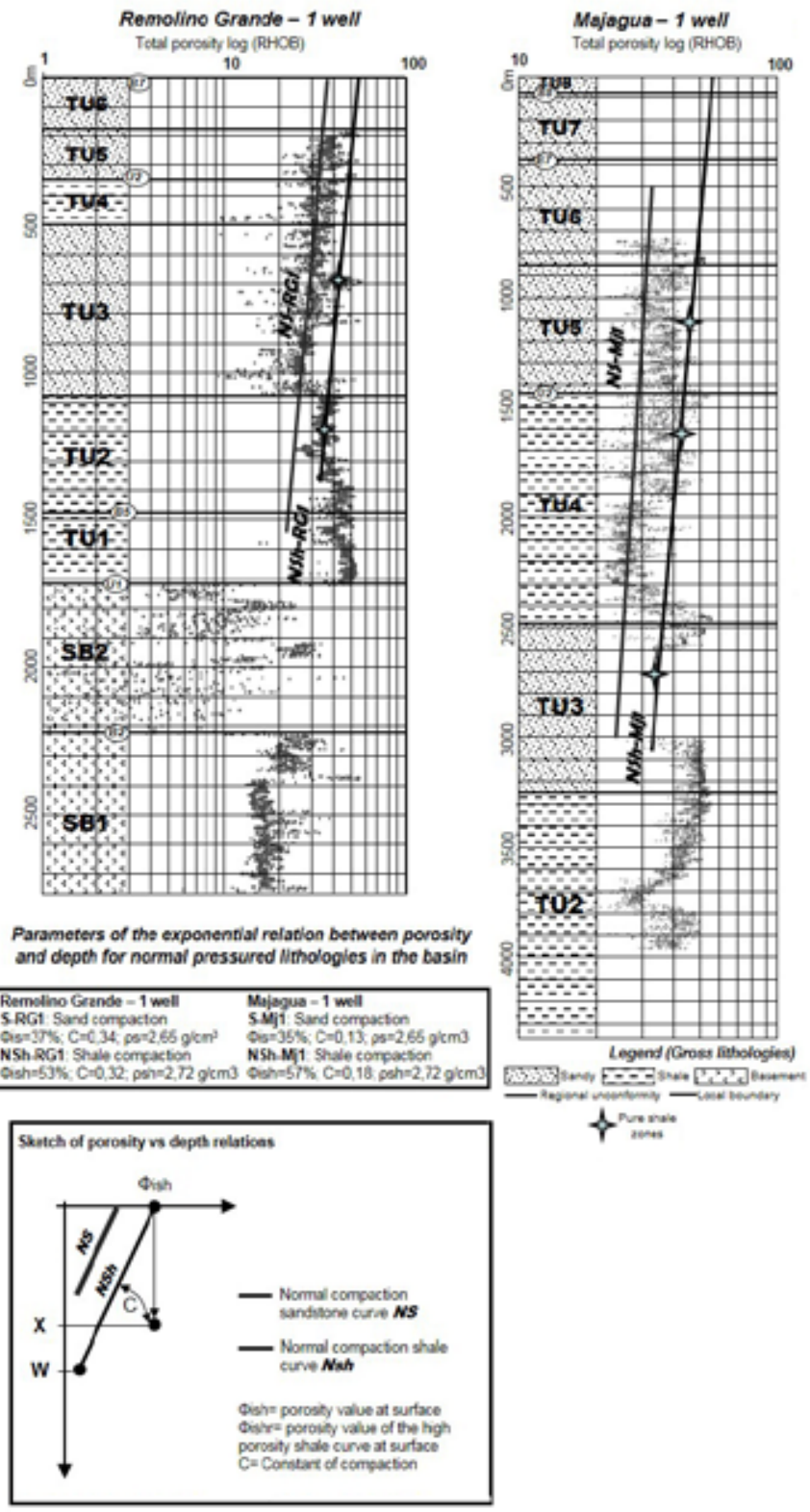

Figure 18. Sandstone (Sd) and shale (Sh) porosity vs depth curves in Remolino Grande-1 and Majagua-1 wells (Tumaco basin). In each well, the left column shows the generalized lithology of each seismic sequence ( $\mathrm{TU}=$ Tumaco basin sequence; $\mathrm{SB}=$ Basement sequence), local sequence boundaries (B) and regional sequence boundaries (U). The right column shows: the porosity distribution in shales and sandstones as estimated from bulk density logs (little gray points), zones of pure shale according to the gamma ray log (gray starts) and the obtained best fit compaction trend lines (see sketch in the upper right side). Obtained parameters of the linear relations are summarized in the lower left side of the figure.

the Pleistocene (Figures 5, 6 and 16). Most of the sediments were accumulated during this time in the Manglares OFAB, with rates of accumulation of nearly $1300 \mathrm{Ton} / \mathrm{My} / \mathrm{m}^{2}$. This value is quite high and is probably related to low temporal resolution available for Pleistocene Holocene sediments. 

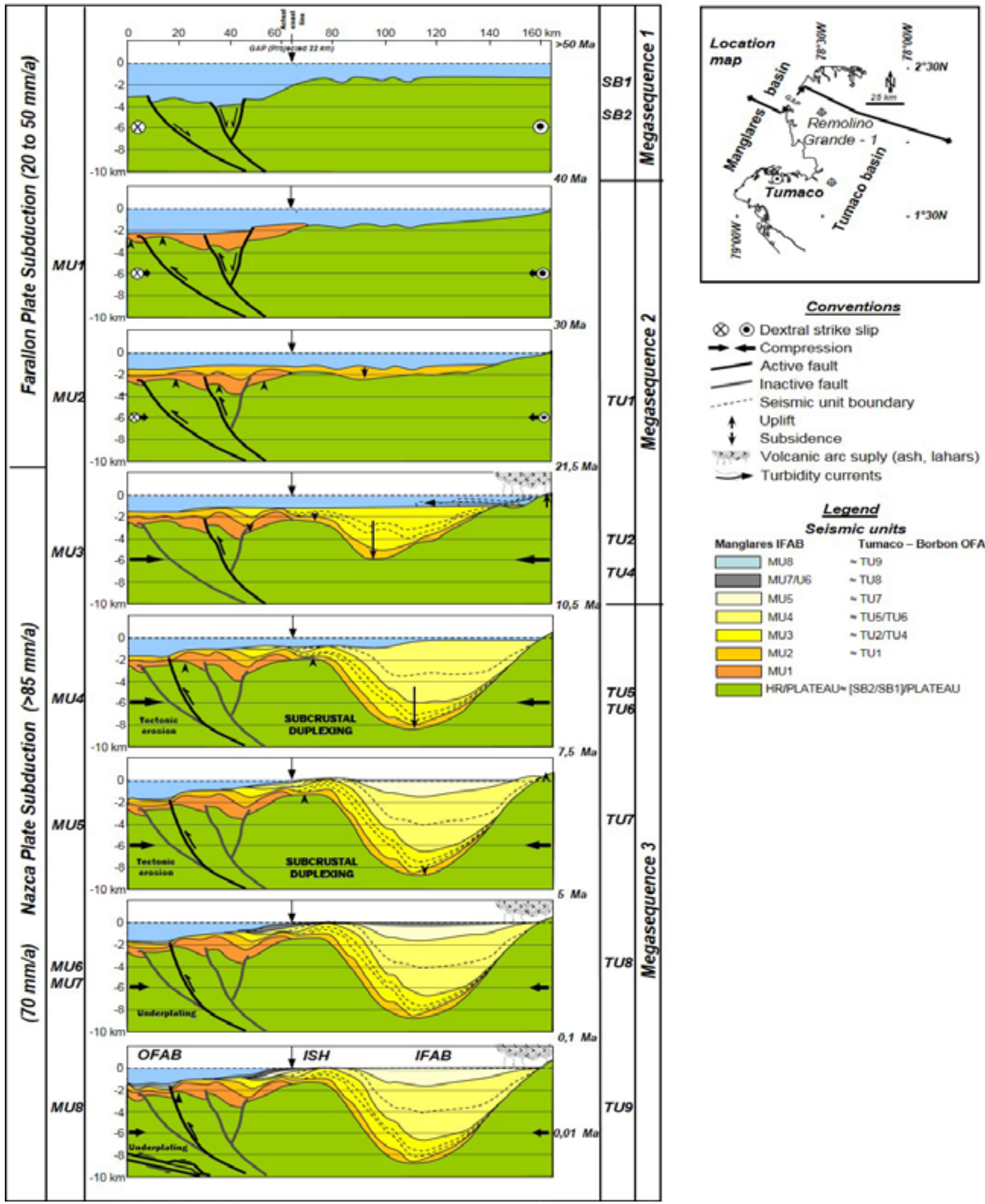

\section{Conventions}

$\otimes \odot$ Dextral strike slip

$\rightarrow \leftarrow$ Compression

- Active fault

Inactive fault

....... Seismic unit boundary

$\uparrow$ Uplift

$\downarrow$ Subsidence

70.0 Volcanic arc suply (ash, lahars)

$\longrightarrow$ Turbidity currents

\begin{tabular}{|c|c|}
\hline & ggend \\
\hline res IFA & mic units \\
\hline Mus & $\begin{array}{l}\text { Tumaco-Borbon C } \\
\text { - TU9 }\end{array}$ \\
\hline MU7Nu6 & $\approx$ Tus \\
\hline MU5 & - TU7 \\
\hline MU4 & - TU5/TU6 \\
\hline mus & - TU2/TU4 \\
\hline MU2 & $\approx$ TU1 \\
\hline MU1 & \\
\hline HRAPL & - (18B2/8B1)pP \\
\hline
\end{tabular}

Figure 19. Integrated northern Manglares Inner Foreac Basin (IFAB) and Tumaco Outer Forearc Basin (OFAB) 2D Airy backstripped profiles at interval times according to the time - slice facies distribution maps of the Figures 9 to 16. Summarized uplift and subsidence mechanism active through the double forearc basin development (sf: splay fault control; Upl: Underplating). Left column shows the subducting plate convergence rate and the right one shows the sequence and megasequences accumulated on the Tumaco - Borbon Inner Foreac Basin (IFAB) and Manglares Outer Forearc Basin (OFAB), divided by the Remolino - Río Verde Inner Structural High (ISH). To build the merged section, the Manglares backstripped section was projected $22 \mathrm{~km}$ to North. S1 and S2 are considered in this exercise like a basement (unaffected by compaction during the Cenozoic). The legend shows the defined seismic units in both basins. 


\section{RESULTS ANALYSIS}

Based on the results of the paleoenvironmental distribution and subsidence history of the margin, we established the detailed history of the Cenozoic deformation of the NESC margin. To understand the drive mechanisms of the double forearc basin formation, we need to put the basins in their regional crustal context, and consider their position with respect to: (1) the Volcanic Arc Massif zone; (2) the interplate contact zone; 3) the upper mantle wedge. Therefore, we built two crustal models across the margin to consider its 3D structural variations. The northern model cuts across the thick Tumaco basin, whereas the southern one cuts across the thinner Borbón basin (Figure 20)

The crustal sections were built using geological maps [49],[71],[30], regional geological synthesis [36], [72],[73],[31],[74], regional gravimetric models [20],[75], wells and seismic reflection data [17]. Onshore crustal thicknesses were obtained by seismic refraction and gravity models [20],[76],[21]. Offshore crustal thicknesses and the dip of the Nazca plate were taken from multichannel seismic reflection profiles and wide-angle seismic data [19],[22]

\section{THE VOLCANIC ARC MASSIF ZONE}

Considering that the Volcanic Arc Massif zone can affect the forearc basins subsidence by tectonic loading [77], we briefly describe the structures and tectonic styles that conform it (Figure 20). The structure of this zone is controlled by two thrust systems diverging from the Baños Front - Romeral Suture (Figure 20). The western thrust system is characterized by a crustal tectonic wedge, increasing northward in width, from $80 \mathrm{~km}$ to $125 \mathrm{~km}$ (Figure20), and by eastward gradual increase of the fault dips from $20-30^{\circ}$ (Toachi-Timbiquí Shear) up to $80^{\circ}$ near the orogen axis. An eastward thinning of the tectonic slices is also observed. The eastern thrust system is about half the width of the western thrust system, and it is produced by dextral strike slip faults forming the sub Andean front.

The western thrust system could correspond to three accretional - collisional events, which stacked oceanic slices along the Baños Front - Romeral Suture during the Mesozoic, according to

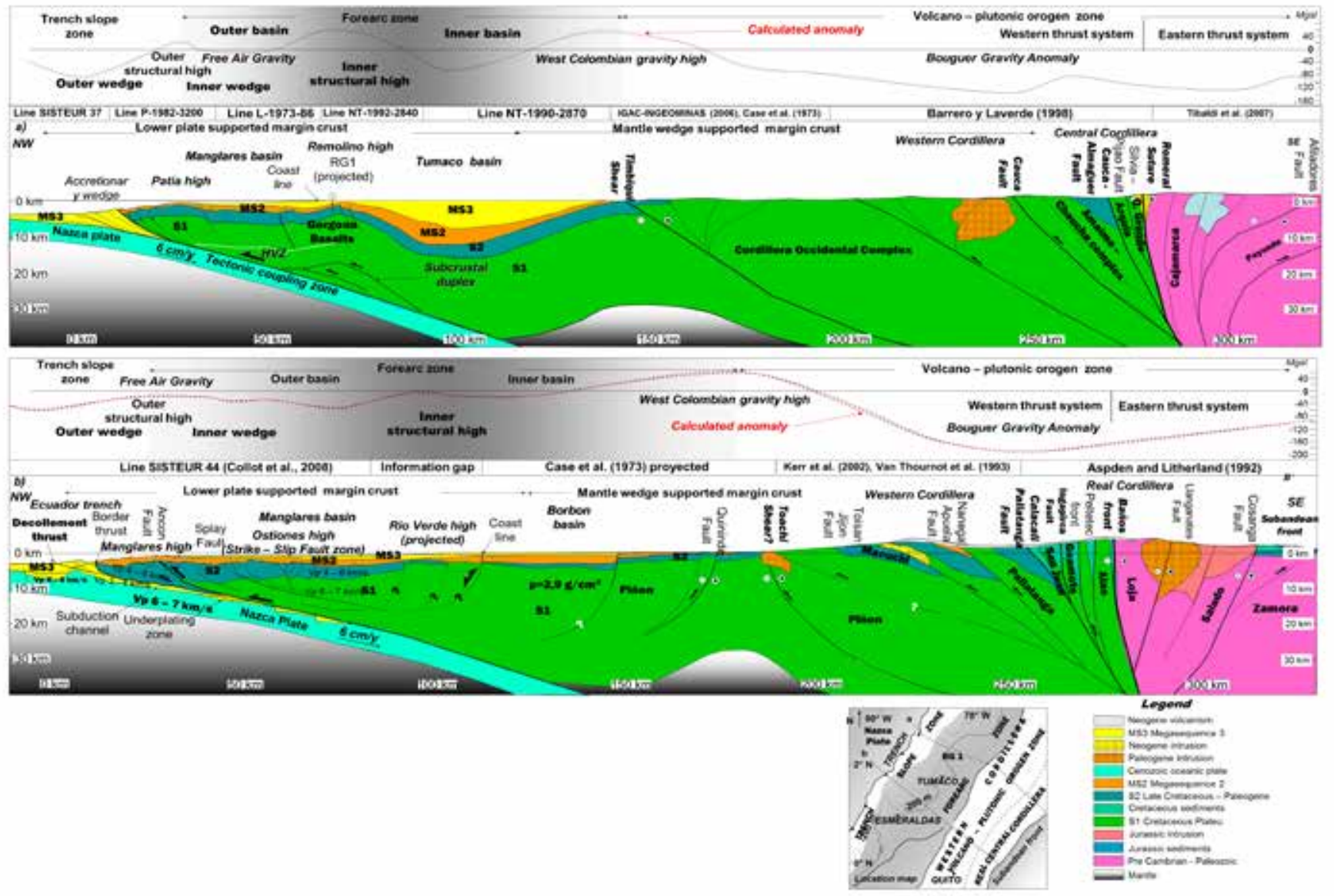

Figure 20. Regional cross sections from the Colombia - Ecuador trench through the Western and Central - Real cordilleras to the Subandean front. Seismic, well and surface geological data are indicated above each section. Stratigraphic units shown in these sections are based on the sequence defined in this work. Well expression of the Tumaco - Borbón IFAB and Manglares OFAB, that compose a double forearc basin is observed in the Northern section (A - A'), whit thick thickness for the megasequences 2 and 3. Southern (section B- B'), the thickness of the megasequences 2 and 3 is decreasing. Note the location of the 1958 earth quake according to Collot [22] that defines the location of the seismogenic zone (note that coseismic slip matches with the splay fault). Gravimetrical data from [20], [98], [97], [96] and [94]. The Northern section (A - A') decollement and the tectonic coupling zone location was obtained from [19] and [93], crustal gravimetric model and density values from [75], [20] and [21]. Calculated gravimetric anomaly resulted from GM-Sys modelling of the crustal blocks shapes (taken from López [75]). 
geological and geochemical works [36],[72],[31];[74]. The eastern thrust system is transpressional, with a significant compression component normal to the faults. It controls the eastward oblique thrusting of metamorphic units of the present sub Andean front [78],[79], after Maastrichtian times.

\section{THE FOREARC - TRENCH SLOPE ZONE}

At a regional scale, the forearc zone tends to decrease northward in width and mafic crustal thickness, while the ISH expression and the thickness of megasequences 2 and 3 increase (Figure 20). Both crustal sections suggest that the forearc basins were developed over a transition between mantle-supported and lower plate-supported crust. The crust of the forearc zone that extends from the continent to the axis of the Tumaco - Borbón IFAB rests directly over the mantle wedge according to gravity modeling $[20,[76],[75]$, defining the domain of the mantle wedge-supported crust (Figures 20 and 21). Wide angle seismic [22],[21] and gravity data [20],[76],[75] show that the crustal thickness of this domain tends to decrease beneath the West Colombian gravity high defined by Case [20]. In addition to a locally shallow mantle wedge, mafic to ultramafic rocks incorporated in the crust could account for the gravity high [20],[76],[21].

The report of ultramafic tectonic slices of Timbiqui shear confirms the ultramafic and mantle origin of the West Colombian gravity high. Although this domain is affected by regional strike slip faults and shear zones (Jama - Quininde, Toachi and Timbiqui), there is no geologic and seismic evidence for a large west-verging crustal thrust beneath the Tumaco basin eastern flank. Therefore, instead of having the foredeep structure that would be expected in a tectonic loading model, beneath the eastern flank of the Tumaco basin, these data rather provide clear evidence of buckling of the crust supported by an upraised mantle. These observations suggest that the Tumaco basin did not originate by tectonic loading (Figures 5, 19 and 20).

To the east of the axis of the TumacoBorbón IFAB, the crust of the forearc zone is supported by the down-going Nazca plate up to the trench, defining the domain of the lower plate-supported crust (Figures 20 and 21). Based on seismological and divides into an aseismic updip segment and a seismogenic zone [22];[80], respectively associated with outer and inner wedges (Figure 20). The updip segment is interpreted to be poorly coupled, in contrast with the seismogenic zone, which is locked during the inter-seismic period. We make a distinction of these two segments of the plate interface because their mechanical behavior may control the formation and extent of the Outer Forearc Basin. the Ultramafitas de Guapi [30] along the geodetic studies [80], the plate interface
According to the seismological studies [81]-[84], the Tumaco IFAB and Remolino - Río Verde ISH are located over the landward part of the seismogenic zone. The sedimentary and paleoenvironmental evolution - described previously in this work -, show that the ISH started uplifting diachronously between the lower and upper Miocene, thus dividing the initial forearc basin into the Tumaco IFAB and Manglares OFAB. This tectonic history shows that the Remolino - Río Verde ISH is not a paleo-structure inherited from the pre-accretion history of the oceanic plateau but, the Remolino - Río Verde ISH was formed during the Miocene by subduction process. Based on fault related fold geometry, [23] proposed that the Remolino ISH could have formed by crustal duplexing (Figure 20). In the Cascadia forearc, similar crustal thickening of an ISH was interpreted as a result of crustal duplexing, close to the mantle wedge [27].

Seaward of the ISH, the Manglares OFAB is located over the seismogenic zone of the plate interface. The basement of the basin is characterized by faulted crustal blocks resulting from a

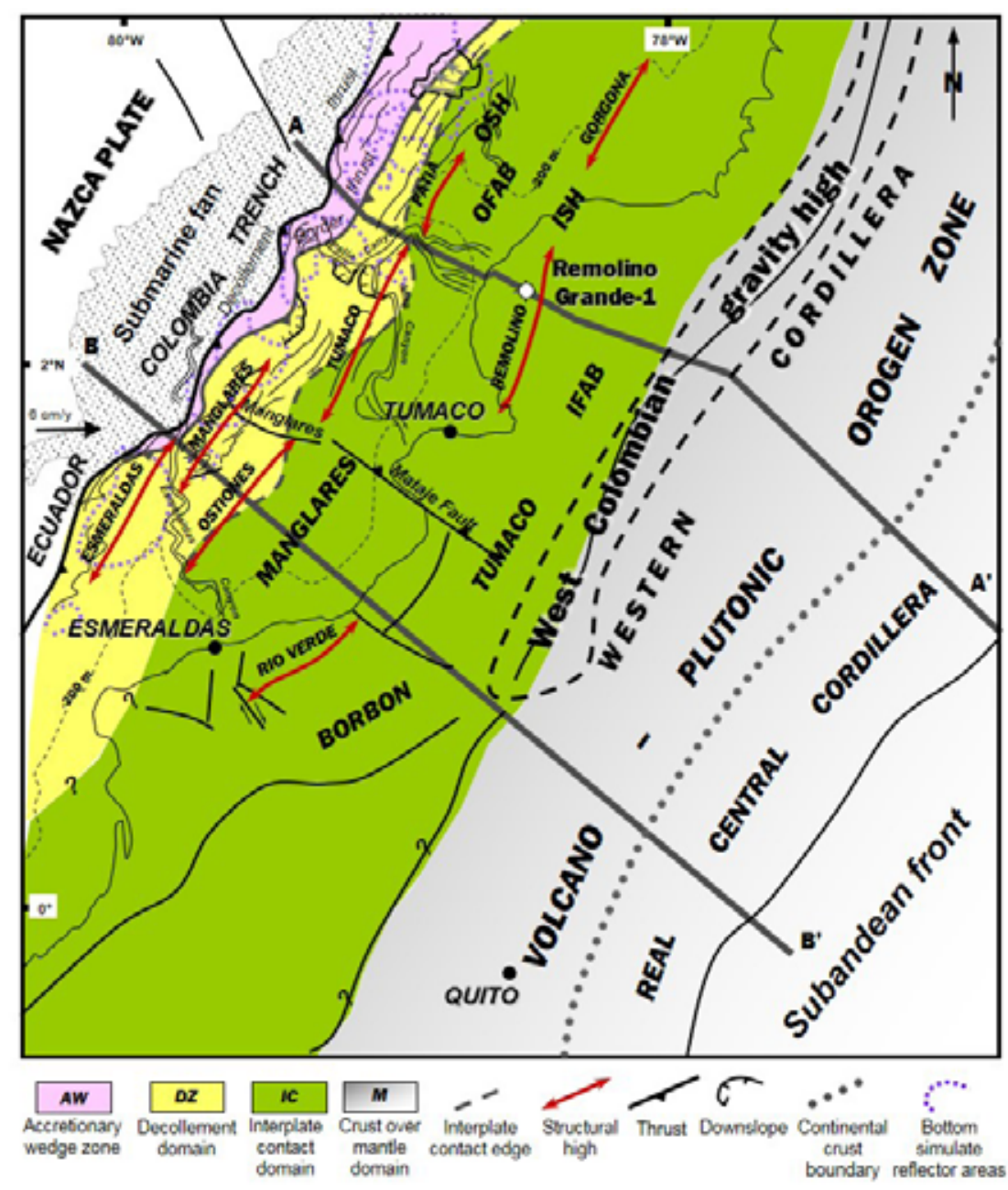

Figure 21. Tectonic map with the distribution of the mantle wedge and lower plate supported domains, and distribution of structures map in the southwestern Colombia and Northern Ecuador area, according to published interpreted seismic lines [22] [93]; [18], gravimetric maps [20]; Collot \& TEAM, 2005; [96], [94] and crustal models [20]; [21]. Dark gray thick lines show the regional cross section location of the Fig. 20. Light blue dotted lines show the areas with Bottom Simulate Reflector according to Collot [22] 
series of tectonic phases that included rifting, tectonic inversion by strike-slip faulting, and compression [22]. Since $-40 \mathrm{Ma}$ the basin development was controlled by this complex tectonic history [17], probably related to the tectonic behavior of the interplate contact. The seaward border of the basin is characterized by OSH in the southern area and slope basins northward. The vertical tectonics of this border appears to have been controlled by the splay fault and Ancon fault [22], which developed at the transition between the aseismic updip zone of the plate interface, and the seismogenic zone (Figure 20)

\section{PROPOSED MODEL FOR THE DOUBLE FOREARC BASIN OF THE NESC MARGIN DURING THE CENOZOIC}

Both crustal models (Figure 20) were restored kinematically at the end of each megasequence (1 to 3 ), to examine the influence of the plate interaction over the development of the double forearc basin (Figures 22 and 23). Our restorations take into account unfolding crustal structures and the offsets along the faults, together with some frontal erosion that is difficult to quantify. The width of the margin was estimated according to the position of the Volcanic Arc Massif zone at each megasequence time. The forearc basins thicknesses in the restored sections were constrained by
2D backstripping analysis (Figure 19). These restorations also consider slab dip changes over time in accordance with kinematic models [85],[69], as well as the lithospheric transition between the Farallon and Nazca plates.

\section{MARGIN CRUSTAL STRUCTURES AT THE END OF MEGASEQUENCE 1 ( 40 Ma)}

Considering the same amount of unknown frontal erosion in both crustal models, our restoration at the end of Megasequence 1 indicates that the arc - trench gap was shorter in the north than in the south thus, suggesting a greater slab dip in the North (Figures 22a and 23a). The Volcanic Arc Massif was emerged, and the crust was locally thicker than $-30 \mathrm{~km}$ and was deformed by thrust systems west of the Baños Front - Romeral Suture.

The region of the accreted oceanic plateau extending west of the western thrust system up to the Toachi - Timbiqui shear zone was poorly affected by faulting. The thickness of the plateau overlain by Megasequence 1 reached $\sim 40 \mathrm{~km}$ in the North (Figure 22a), and varied between $\sim 20$ to $40 \mathrm{~km}$ in the South (Figure 23a). Between the Toachi - Timbiqui shear zone and the Jama - Quininde Fault, the crustal thickness reached only $\sim 20 \mathrm{~km}$. Westward of this area

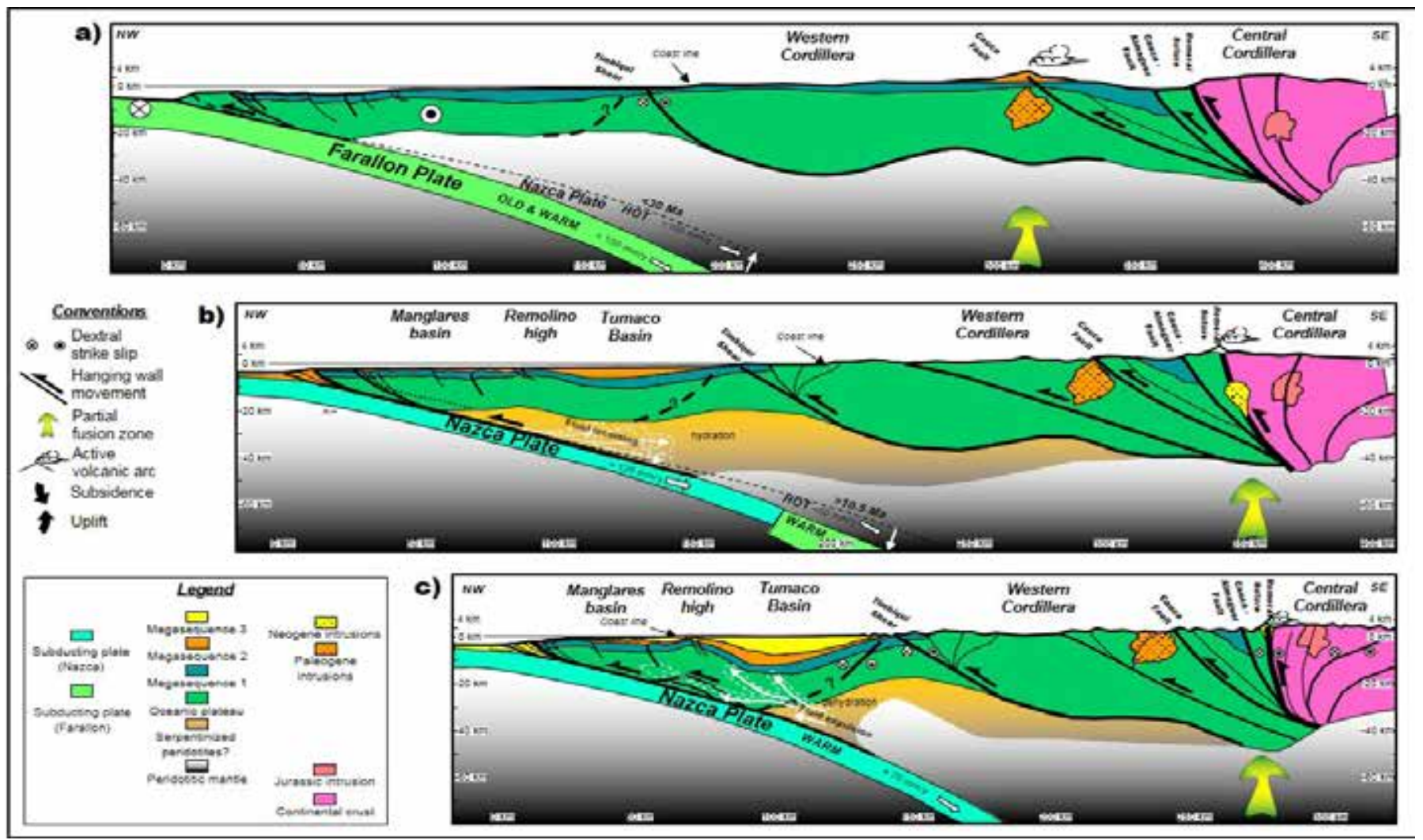

Figure 22. Simplified regional cross section from the Central Cordillera through the Western Cordillera to the Northern Manglares - Tumaco forearc basin according to the section of the Fig. 20 A. Megasequences shown in the section are based on the sequence stratigraphy (see the paleogeographic position of each section in the Fig. 21). At $40 \mathrm{Ma}$ (Section a), the restoration suggests westward blocky faulting (transpression) and eastward thrusting of slides of oceanic plateau and volcanic rocks. At $10.5 \mathrm{Ma}$ (Section b), at top of the megasequence 2 the restoration suggests tectonic erosion $(\approx 20 \mathrm{~km})$ and shortening $(\approx 25 \mathrm{~km})$ during the Nazca plate subduction rate increasing. The restoration at the top of the megasequence 1 (Section $\mathrm{c}$ ), suggests others $\approx 60 \mathrm{~km}$ of section shortening, $\approx 25 \mathrm{~km}$ of eroded margin, regional cordilleras uplifting and $\approx 4 \mathrm{~km}$ of basement subsidence in the Tumaco basin Probably partially hydrated to dehydrated mantle wedge process occurred by the subducting plate changes (Farallon to Nazca) and their convergence velocities variations [89];[85], that favored the overriding plate alteration and the formation of subcrustal duplex by tectonic erosion, that divided the forearc basin zone in the Manglares and Tumaco basins. 


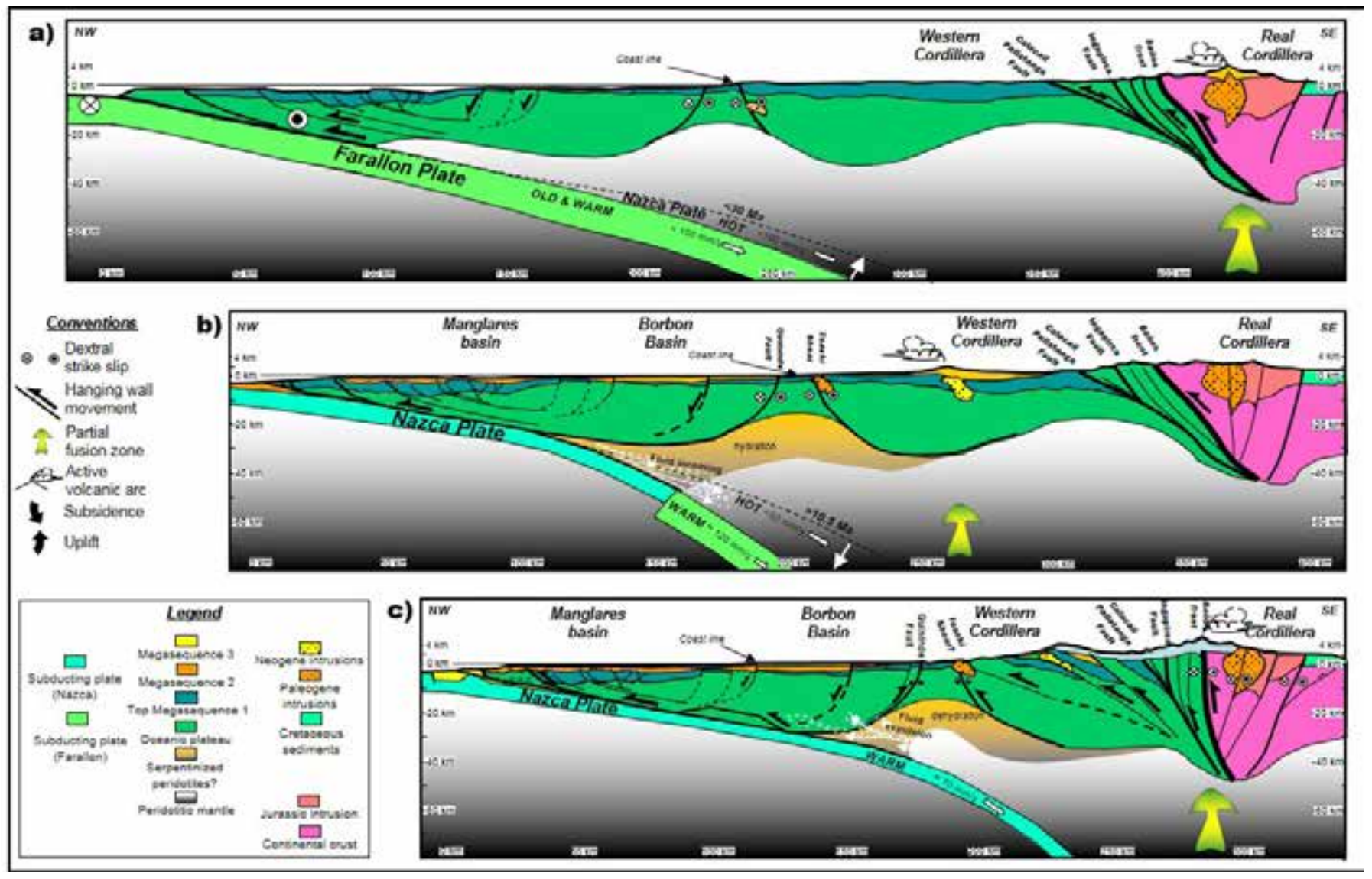

Figure 23. Simplified regional cross section from the Real Cordillera through the Western Cordillera to the Southern Manglares Borbón forearc basin according to the section of Fig. 20 B. Megasequences shown in the section are based on the sequence stratigraphy (see the paleogeographic position of each section in the Fig. 21). At $40 \mathrm{Ma}$ (a), the restoration suggests westward blocky faulting (transpression) and eastward thrusting of slides of oceanic plateau and volcanic rocks. At $10.5 \mathrm{Ma}$ (b), at top of the megasequence 2 the restoration suggests tectonic erosion $(\approx 50 \mathrm{~km})$ and shortening $(\approx 30 \mathrm{~km})$ during the Nazca plate subduction rate increasing. The restoration at the top of the megasequence 1 (c), suggests others $\approx 50 \mathrm{~km}$ of section shortening, $\approx 30 \mathrm{~km}$ of eroded margin and slow basement subsidence in the Borbón basin. Probably partially hydrated to dehydrated mantle wedge process occurs by the subducting plate changes (Farallon to Nazca) and their convergence velocities variations [21]; [85], which favored the overriding plate alteration and the formation of subcrustal duplex by tectonic erosion, which divided the forearc basin zone in the Manglares and Borbón basin.

of crustal slimming, the margin was under sea level, and its crust probably reached $\sim 40 \mathrm{~km}$ in thickness to the South of the Mataje - Manglares fault, while to North, the crust possibly reached a 30 $\mathrm{km}$ maximum thickness (Figures 22a and 23a). Between 50 and $40 \mathrm{Ma}$, the Farallon Plate subducted beneath the margin (Figure 24a), and the oblique convergence direction and rate tended to decrease from $150 \mathrm{~km} /$ My to less than $100 \mathrm{~km} / \mathrm{My}$ [85],[69].

According to various models, a decreasing convergence rate may produce a trenchward advance of isotherms [3];[4], a slab dip decrease [6], and a significant increase of the interplate coupling and crustal erosion [7]. As a result of these changes, the overriding plate suffers an additional horizontal compressional stress [5]. The decrease in convergence rate may also produce a stop or a landward migration of the magmatic arc, a thermal contraction in the forearc zone [86], a dehydration of the mantle wedge [3], and an increase of the tectonic erosion [87].

Based on these processes, we suggest that at the end of Megasequence 1, while the convergence rate of the Farallon Plate was diminishing, the slab dip decreased from South to North and, consequently, the interplate coupling increased and the overriding plate tended to shorten by wrenching (Figure 23a), in response to the very oblique convergence [88],[69].

\section{MARGIN CRUSTAL STRUCTURES DEVELOPED AT THE END OF MEGASEQUENCE 2 ( 10,5 Ma)}

The restored sections at the end of the Megasequence 2 indicate that the arc - trench gap width decreased at least by $\sim 25 \mathrm{~km}$ since the end of Megasequence 1, as estimated along the faults of the western thrust system (Figures 22b and 23b). This shortening implied thickening of the Western Cordillera by stacking of crustal slices, while the strike slip component of the convergence was decreasing [69].

By the end of Megasequence 2, the double forearc basin was fully created as a result of the uplift of the Remolino - Río Verde ISH and the high sediment supply from the Andes (Figures 22b and 23b). However, subsidence was much larger in the Tumaco IFAB than in the Borbón IFAB (Figure 19). Synchronously, the Manglares OFAB was subject to generalized subsidence and transverse active faulting (Figure 22b and 23b). During deposition of Megasequence 2 , the Farallon Plate began fragmenting [89] into the Nazca and Cocos plates (Figure 24b), and the normal component of the subduction rate increased [90],[69]. 


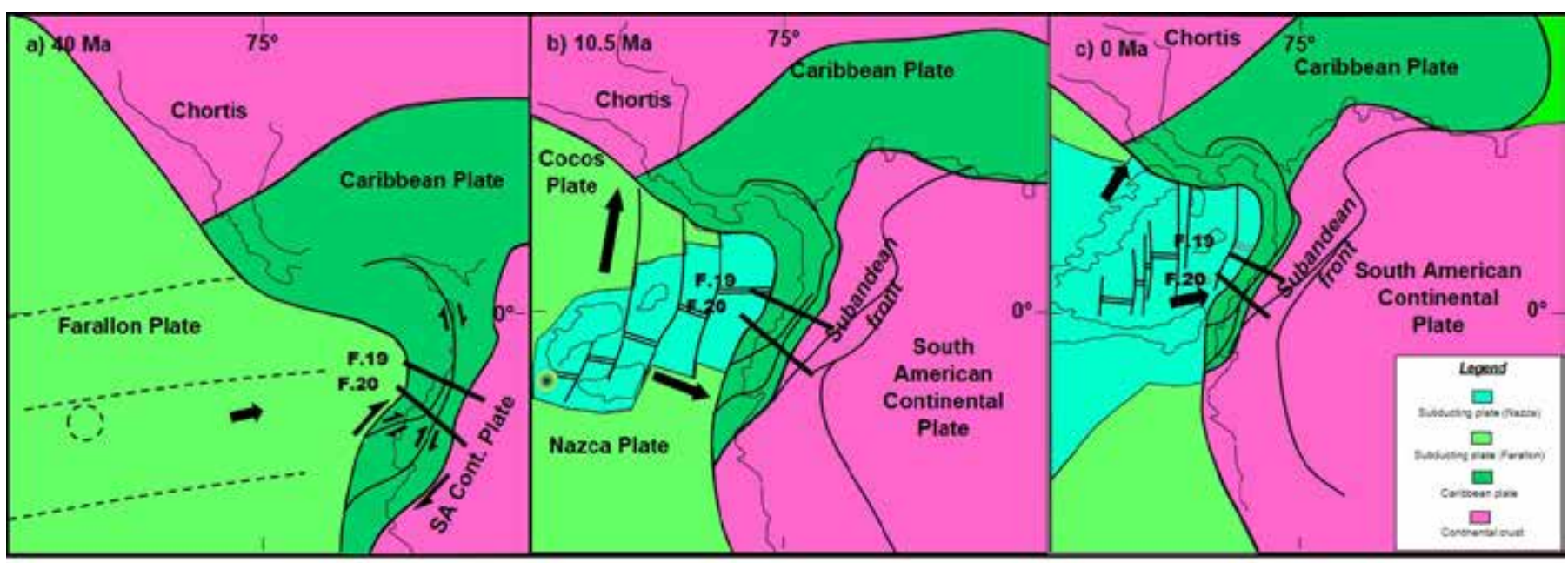

Figure 24. Simplified regional paleogeographic positions of the plates according to [90], [67] and [92]. The thick black line shows the cross-section position of the Figs. 22 and 23. At 40 Ma the restoration (Map a) suggesting regional transpression that favored the thrusting of slides of oceanic plateau and volcanic rocks along the continental margin. At 10.5 Ma (Map b), the restoration suggests an increase in the subduction rate of the hot and young Nazca plate rate below the South American margin. The restoration today (Map c) suggests regional shortening during the decrease of the convergence rate between the Nazca and South American plates.

According to the model by [6], we associate the convergence rate increase with an increase of the slab dip, which produced isotherms step back from the trench, a cooling of the mantle wedge thermal structure [4], and a decrease of the plates coupling and tectonic erosion [7]. As a result, the horizontal compressional stress decreases in the forearc [5], the mantle hydration increases [91],[3], and the subsidence rate increases in areas of thin forearc crust [4].

Considering these kinematic and structural relationships, we suggest that during Megasequence 2, the increased generalized subsidence or reduced local uplifts in the forearc zone resulted from a slab dip increase. As the convergence rate of the Farallon Plate was increasing, the slab dip increases were likely to result in mantle wedge hydration, diminishing the plates coupling and allowing the subsidence to concentrate on forearc areas with thin crust as it was shown in the case of the Los Angeles basin [4]. Hence, the Tumaco IFAB would have initiated in an area of thin crust relative to the crust of the Borbón IFAB and Western Cordillera.

\section{MARGIN STRUCTURES DEVELOPED AT THE END OF MEGASEQUENCE 3 ( 10-0 Ma)}

At the end of the accumulation of Megasequence 3, the margin structure and geometry are characterized by the $300 \mathrm{~km}$-wide arc - trench gap in the South (Figure 23c), which is only $-250 \mathrm{~km}$ wide in the North (Figures 22c). The coast line migrated seaward with respect to its position by the end of Megasequence 2, to be established west of the Remolino - Río Verde ISH. During the accumulation of Megasequence 3, the Volcanic Arc Massif zone was shortened by up to $50 \mathrm{~km}$. In the double forearc basin zone, subsidence increased and concentrated in the Tumaco IFAB, whereas uplift dominated in the Borbón IFAB and Manglares OFAB (Figures 22c and 23c).

During the last $10 \mathrm{Ma}$, the crustal thickness increases below the Remolino - Río Verde ISH, probably by sub crustal duplexing process [23] and the outer margin wedge was eroded tectonically [22]. Synchronously, the plate convergence decreased from $>120$ $\mathrm{km} /$ My to $<100 \mathrm{~km} / \mathrm{My}$ [85] and the Malpelo rift died (Figure 24c) [90]; [92].

Considering that a slab dip decrease is associated with the decrease of the plate convergence rate, we infer that the area and coupling of the interplate contact increased, thus submitting the forearc system to shortening. These interplate contact processes would be responsible for the compressive deformation and exhumation of the Volcanic Arc Massif zone [53], and the generalized uplift in the forearc zone. In this scenario, the huge sediment accumulation in the Tumaco IFAB, in absence of crustal faulting, would have resulted from crustal buckling due to horizontal stress transfer into the overriding plate.

The increase in area of interplate contact also supports other processes allowing the tectonic deformation to concentrate in some point of the inner wedge and facilitate the development of the double forearc basin. We have inferred that the ISH that divides the forearc area into the Tumaco - Borbón IFAB and Manglares OFAB resulted from crustal duplexing. Such duplexing has been shown to occur on the fully coupled interplate contact area [27] where rocks have been altered by fluids derived from the mantle wedge [3]. Such a process is very likely to occur during a period of slab dip decrease when the area of interplate contact tends to increase. We propose that the duplexing beneath the Remolino Río Verde ISH was facilitated by the alteration of the overriding plate by fluid expulsed from the mantle wedge (Figure 23c). At the same time, the sediments accumulated along the trench was partially involved into the accretionary wedge and increase the uplift activity in the $\mathrm{OSH}$ zone. 


\section{CONCLUSIONS}

The chronostratigraphic correlation developed across the NESC forearc system provides evidences for eight Seismic Sequences in the Manglares basin (MU1 to MU8) and eleven Seismic Sequences in the Tumaco basin (SB1, SB2, and TU1 to TU9). The sequences SB1 and SB2 have either, volcanic or volcano sedimentary origin, while the other sequences have a sedimentary origin. Two of these boundary surfaces (U1 and U2), represent regional unconformities that bound three megasequences of regional extent. The age of the regional unconformities coincides with the occurrence of global sea level fall events.

A major unconformity (U1) characterized by a variable hiatus time gap allows to group sequences SB1 and SB2 into preLate Eocene Megasequence 1. The base of Megasequence 1 is composed of Mesozoic oceanic basement rocks accreted against the continental margin along the Baños Front - Romeral Suture, between the Late Maastrichtian to Early Eocene. The margin was deformed by transpression, in a strongly oblique convergence setting, and affected by a strong volcanic activity responsible for the accumulation of the SB2 rocks.

Megasequence 2 is composed of mass transport, turbiditic and deep-water sediments (MU1 - 3 and TU1 - 4), which deposited between the Late Eocene and the early Late Miocene. A change from transpression to compression helped to form a double forearc basin, with bypass sedimentation periods. The overfilling of the forearc basins during the Late to Middle Miocene allowed to record the sea level changes of second or higher order.

The deep-water sediments that conform Megasequence 2 were covered by large thicknesses of sediments accumulated in shallow water to continental fans, augmented by large contributions of volcanic material eroded from the active volcanic arc (Megasequence 3). The high amount of supplied sediments overfilled the Tumaco - Borbón IFAB and bypass toward the Manglares OFAB at the end of the Miocene up today. The bypass was controlled by the ISH uplift activity. The high sediment supply rates accumulated in the Tumaco IFAB submitted the sediments of the megasequence 2 to overpressure and forms shale diapirs. Additionally, faults transverse to the margin (Mataje - Manglares Fault), divided partially the Tumaco - Borbón IFAB and Manglares OFAB, controlling the distribution of sediments and sedimentary environments in the area.

The crustal sections in the area suggest that the forearc zone can be divided in two domains as the support of the overriding plate. The first domain is characterized by the mantle wedgesupported margin crust, thick sedimentary sequences and wide basins. The second domain, located in the central part of the area is characterized by the lower-plate supported margin crust, a regional subcrustal duplexing, strike slip structures, variable thickness of sedimentary sequences, and narrow basins.

Restored sections and the stratigraphic evolution of the forearc system indicate that at the end of Megasequence 1 , the oblique convergence of the Farallon Plate and the interplate coupling increase submitted the margin to transpression. During the development of Megasequence 2, the increase in the normal convergence to the margin of the Farallon Plate in process of fragmentation and the strong interplate coupling subjected the margin to compression. At the end of the megasequence 2 accumulation, the increase in the convergence rates of the subducting plate produced a partial hydration of the mantle wedge. It led to a strong subsidence on forearc areas with thin crust. Finally, during the development of Megasequence 3, the decrease in the convergence rates of the fragmented Farallon Plate, diminishes the slab dip of the subducting plate and submitted the margin to compression and crustal buckling. Additionally, the slab dip decrease allowed partial dehydration of the mantle wedge, altering the overriding plate, and facilitating the formation of crustal duplexes near the interplate contact, thus uplifting the inner structural high.

\section{ACKNOWLEDGEMENTS}

We are grateful to the Institut de Recherche pour le Développement (IRD) for funding and providing access to AMADEUS cruise samples and reports. We especially thank the anonymous reviewers and the editorial Committee of CTEF by the patient review, correction and recommendations to improve the content and form of this work. Special thanks to my wife for her patient review and correction of the final English text.

\section{REFERENCES}

[1] Hartley, A. J., May, G., Chong, G., Turner, P., Kape, S. J., \& Jolley, E. J. (2000). Development of a continental forearc: A Cenozoic example from the Central Andes, northern Chile. Geology. https://doi.org/10.1130/00917613(2000)028<0331:DOACFA > 2.3.CO;2

[2] Xie, X., \& Heller, P. L. (2009). Plate tectonics and basin subsidence history. Bulletin of the Geological Society of America. https://doi.org/10.1130/B26398.1
[3] Hyndman, R. D., \& Peacock, S. M. (2003) Serpentinization of the forearc mantle. Earth and Planetary Science Letters. https://doi.org/10.1016/ S0012-821X(03)00263-2

[4] Mikhailov, V. O. Parsons, T. Simpson, R. W.. Timoshkina, E. P., \& Williams, C. (2007). Why the Timoshkina, E. P., \& Williams, C. (2007). Why the
sacramento delta area differs from other parts of the great valley: Numerical modeling of thermal structure and thermal subsidence of forearc basins. Izvestiya, Physics of the Solid Earth. https://doi.org/10.1134/ S1069351307010089

[5] Boutelier, D. A., \& Cruden, A. R. (2008), Impact of regional mantle flow on subducting plate geometry and interplate stress: Insights from physical modelling Geophysical Journal International. https://doi. org/10.1111/j.1365-246X.2008.03826.x 
[6] Lallemand, S., Heuret, A., \& Boutelier, D. (2005). On the relationships between slab dip back-arc stress, upper plate absolute motion, and crustal nature in subduction zones. Geochemistry, Geophysics, Geosystems. https:// doi.org/10.1029/2005GC000917

[7] Spencer, J. E. (1994). A numerical assessment of slab strength during high- and low-angle subduction and implications for Laramide orogenesis. Journal of Geophysical Research. https://doi. org/10.1029/94JB00503

[8] Bailleul, J., Robin, C. Chanier, F., Guillocheau, F., Field, B., \& Ferriere, J. (2007). Turbidite Systems in the Inner Forearc Domain of the Hikurangi Convergent Margin (New Zealand): New Constraints on the Development of Trench-Slope Basins. Journal of Sedimentary Research. https://doi.org/10.2110/jsr.2007.028

[9] Karig, D. E., Lawrence, M. B., Moore, G. F., \& Curray, J. R. (1980). Structural framework on the fore- arc basin, NW Sumatra. Journal of the Geological Society. https:// doi.org/10.1144/gsjgs.137.1.0077

[10] McNeill, L. C., Goldfinger, C., Kulm, L. V.D., \& Yeats, R. S. (2000). Tectonics of the Neogene Cascadia forearc basin: Investigations of a deformed late Miocene unconformity. Bulletin of the Geological Society of America. https://doi.org/10.1130/00167606(2000)112<1209:TOTNCF>2.0.CO;2

[11] Noda, A. (2016). Forearc basins: Types, geometries, and relationships to subduction zone dynamics. Bulletin of the Geological Society of America. https://doi. org/10.1130/B31345.1

[12] Dickinson, W. R., \& Seely, D. R. (1979). STRUCTURE AND STRATIGRAPHY OF FOREARC REGIONS. AAPG Bull. https://doi.org/10.1306/ce5387c3

[13] Barnes, P. M. Nicol, A.. \& Harrison, T. (2002). Late Cenozoic evolution and earthquake potential of an active listric thrust complex above the Hikurangi subduction zone, New Zealand. Bulletin of the Geological Society of America. https://doi.org/10.1130/00167606(2002)114<1379:LCEAEP>2.0.CO;2

[14] Lewis, K. B., \& Pettinga, J. R. (1993). The emerging, imbricate frontal wedge of the Hikurangi margin. In P. F. Ballance (Ed.), Sedimentary Basins of the World 2 (pp. 569-578). Elsevier

[15] Ranero, C. R., Von Huene, R., Flueh, E., Duarte, M., Baca, D., \& Mclntosh, K. (2000). A cross section of the convergent Pacific margin of Nicaragua. Tectonics. https://doi.org/10.1029/1999TC900045

[16] Bueno, R. (1989). Hydrocarbon exploration and potential of the Pacific costal basin of Colombia In G. E. Ericksen, M. T. Canas Pinochet, \& J. A. Reinemund (Eds.), Geology of the Andes and its relation to hydrocarbon and mineral resources. (pp. 335-343). Circum-Pacific Council for Energy and Mineral Resources Earth Sciences Series.

[17] López, E. (2009). Evolution tectono-stratigraphique du double bassin avant - arc de la marge convergente Sud Colombienne - Nord Equatorienne pendant le Cénozoïque. GeoAzur.

[18] Marcaillou, B., \& Collot, J. Y. (2008). Chronostratigraphy and tectonic deformation of the North Ecuadorian-South Colombian offshore Manglares forearc basin. Marine Geology. https://doi.org/10.1016/j. margeo.2008.07.003

[19] Agudelo, W. (2005). Imagerie sismique quantitative de la marge convergente d'Equateur-Colombie Application des mèthodes tomographiques aux données de sismique réflexion multitrace et réfraction-réflexion grand-angle des campagnes SISTEUR et SALIERI Universit'e Paris.

[20] Case, J. E., Barnes, J., ParíS Q., G., GonzáLez l., H., \& ViñA, A. (1973). Trans-andean geophysical profile, southern Colombia. Bulletin of the Geological Society of America. https://doi.org/10.1130/00167606(1973)84<2895:TGPSC>2.0.CO;2

[21] Meissnar, R. O., Flueh, E. R., Stibane, F., \& Berg, E. (1977). Dinamica del limite de placas activo en el SW de
Colombia, deacuerdo a recientes mediciones geofisicas. In J.E. Ramirez (Ed) La transicion océano - continente en el suroeste de Colombia (pp. 169-198). Instituto Geofisico - Universidad Javeriana.

[22] Collot, J. Y., Agudelo, W., Ribodetti, A., \& Marcaillou, B. (2008). Origin of a crustal splay fault and its relation to the seismogenic zone and underplating at the erosional north Ecuador-south Colombia oceanic margin. Journal of Geophysical Research: Solid Earth. https://doi. org/10.1029/2008JB005691

23] López, E., Collot, J. Y., \& Sosson, M. (2008). Sedimentary constraints on the tectonic evolution of the paired Tumaco-Borbón and Manglares forearc basins (southern Colombia-northern Ecuador) during the Late Cenozoic. Extended Abstract, 7th ISAG, Nice, France.

[24] Bedoya, E. L., Flores, J. A., \& Pardo, A. (2013). Nanofósiles calcáreos y bioestratigrafía del mioceno tardíxo del sw de la cuenca tumaco onshore (pacífico colombiano). Boletin de Geologia.

[25] Bermudez, H. D. (2016). Esquema estratigráfico y paleogeografía del Occidente Colombiano para el Paleógeno tardío y Neógeno. Memorias XII Simposio de Exploración de Cuencas Subandinas, 4

[26] Bermudez, H. D., García, J., Restrepo, L. Ca., Mejía, A. Rey, J. A. Guzmán, W. Bedoya, E. L. \& Numpaque, J. A. (2016). Sistemas deltaicos en el Neógeno de la Cuenca de Tumaco, pacífico Colombiano. Memorias XII Simposio de Exploración de Cuencas Subandinas, 13

[27] Calvert, A. J., Ramachandran, K., Kao, H., \& Fisher, M. A. (2006). Local thickening of the Cascadia forearc crust and the origin of seismic reflectors in the uppermost mantle. Tectonophysics. https://doi.org/10.1016/j. tecto.2006.01.021

[28] Moore, J. C. Diebold, J., Fisher, M. A., Sample, J., Brocher T Talwani, M Ewing J. Huene, R von, Rowe C., Stone, D., Stevens, C., \& Sawyer, D. (1991). EDGE C., Stone, D., Stevens, C., \& Sawyer, D. (1991). EDGE
deep seismic reflection transect of the eastern Aleutian arc-trench layered lower crust reveals underplating and continental growth. Geology, 19(5), 420. https:// doi.org/10.1130/0091-7613(1991)019<0420:EDSRTO $>2.3 . \mathrm{CO} ; 2$

[29] Borrero, C., Pardo, A., Jaramillo, C. M., Osorio, J. A. Cardona, A., Flores, A., Echeverri, S., Rosero, S., García, J., \& Castillo, H. (2012). Tectonostratigraphy of the Cenozoic Tumaco forearc basin (Colombian Pacific) and its relationship with the northern Andes orogenic build up. Journal of South American Earth Sciences. https:// doi.org/10.1016/j.jsames.2012.04.004

[30] IGAC, \& INGEOMINAS. (2006). Investigacion integral del Anden Pacifico Colombiano In Investigacion integral del Anden Pacifico Colombiano - Tomo 1 Geología (p. 165). IGAC.

[31] Kerr, A. C., Aspden, J. A., Tarney, J., \& Pilatasig, L. F. (2002). The nature and provenance of accreted oceanic terranes in western Ecuador: Geochemical and tectonic constraints. Journal of the Geological Society. https:// doi.org/10.1144/0016-764901-151

[32] Lebras, M., Megard, F., Dupuy, C., \& Dostal, J. (1987). Geochemistry and tectonic setting of pre-collision Cretaceous and Paleogene volcanic rocks of Ecuador. Geological Society of America Bulletin. https://doi. org/10.1130/0016-7606(1987)99<569:GATSOP > 2.0 . $\mathrm{CO} ; 2$

[33] Spadea, P., \& Espinosa, A. (1996). Petrology and chemistry of late Cretaceous volcanic rocks from the southernmost segment of the Western Cordillera of Colombia (South America). Journal of South American Earth Sciences. https://doi.org/10.1016/08959811(96)00029-6

[34] van Thournout, F., Hertogen, J., \& Quevedo, L. (1992). Allochthonous terranes in northwestern Ecuador. Tectonophysics. https://doi.org/10.1016/00401951(92)90427-8

35] Kerr, A. C. (2005), La Isla de Gorgona, Colombia: A petrological enigma? Lithos. https://doi.org/10.1016/j. lithos.2005.02.006

[36] Aspden, John A., \& Litherland, M. (1992). The geology and Mesozoic collisional history of the Cordillera Real, Ecuador. Tectonophysics. https://doi.org/10.1016/00401951(92)90426-7

[37] Mamberti, M., Lapierre, H., Bosch, D., Jaillard, E., Ethien, R., Hernandez, J. \& Polvé, M. (2003). Accreted fragments of the Late Cretaceous Caribbean-Colombian Plateau in Ecuador. Lithos. https://doi.org/10.1016/ S0024-4937(02)00218-9

[38] von Huene, R., Fisher, M. A., \& Bruns, T. R. (1987). Geology and evolution of the Kodiak margin, Gulf of Alaska. In D. W. Scholl (Ed.), Geology and resource potential of the continental margin of western North America and adjacent ocean basins-Beaufort Sea to Baja California (pp. 191-212). Circum-Pacific Council for Energy and Mineral Resources.

[39] Van Melle, J., Vilema, W., Faure-Brac, B., Ordoñez, M., Lapierre, H., Jimenez, N., Jaillard, E., \& Garcia, M. (2008). Pre-collision evolution of the Piñón oceanic terrane of SW Ecuador: Stratigraphy and geochemistry of the "Calentura Formation." Bulletin de La Societe Geologique de France. https://doi.org/10.2113/gssgfbull.179.5.433[40] Evans, C. D. R., \& Whittaker, J. E. (1982). The geology of the western part of the Borbón Basin, North-west Ecuador. Geological Society Special Publication. https://doi.org/10.1144/GSL. SP.1982.010.01.12

[40] Dumont, J. F., Santana, E., Valdez, F., Tihay, J. P., Usselmann, P., Iturralde, D., \& Navarette, E. (2006). Fan beheading and drainage diversion as evidence of a 3200-2800 BP earthquake event in the EsmeraldasTumaco seismic zone: A case study for the effects of great subduction earthquakes. Geomorphology. https:// doi.org/10.1016/j.geomorph.2005.07.011

[41] Gansser, A. (1950). Geological and petrological notes on Gorgona Island in relation to North-Western South America. Bull Suisse de Min. et Pet., 30, 219-237.

[42] Stainforth, R. M. (1948). Applied micropaleontology in coastal Ecuador. Journal of Micropaleontology, 22(2), 113-151.

[43] Cantalamessa, G., Di Celma, C., Ragaini, L., Valleri, G., \& Landini, W. (2007). Sedimentology and highresolution sequence stratigraphy of the late middle to late Miocene Angostura Formation (western Borbón Basin, northwestern Ecuador). Journal of the Geological Society. https://doi.org/10.1144/0016-76492006-001

[44] Ordoñez, M., Jimenez, N., \& Suarez, J. (2006). Micropaleontologia Ecuatoriana. Datos bioestratigraficos y paleoecologicos de las cuencas: Graben de Jambeli, Progreso, Manabi, Esmeraldas y Oriente; del levantamiento de la Peninsula de Santa Helena, y de las cordilleras Chongon Colonche, Costera y Occid. PETROPRODUCCION - CIGG.

[45] Cepeda, H. (Ingeominas). (1986). Investigaciones petrologicas en el ambito de las planchas 429 Pasto y 410 La Union, con especial enfasis en el complejo volcanico del Galeras. Boletin Geologico, INGEOMINAS, 30(1), 48-113.

[46] Snedden, J. W., \& Sarg, J. F. (2008). Seismic Stratigraphy - A Primer on Methodology. Search and Discovery.

[47] Vail, P. R. (1987). Seismic Stratigraphy Interpretation Using Sequence Stratigraphy Part I : Seismic Stratigraphy Interpretation Procedure. AAPG Studies in Geology \#27, Volume 1: Atlas of Seismic Stratigraphy.

[48] Hubbard, R. J. (1988). Age and significance of sequence boundaries on Jurassic and Early Cretaceous rifted continental margins. American Association of Petroleum Geologists Bulletin. https://doi. org/10.1306/703c81c8-1707-11d7-8645000102c1865d

[49] CODIGEM, \& BGS. (1993). Mapa Geologico de la República del Ecuador, escala 1:1'000.000 (p. 1 hoja). CODIGEM. 
[50] DGGM. (1980). Mapa geologico del Ecuador, Hojas 24 y 7, Esmeraldas y Punta Galera, escala 1:100.000 (p. 2). Dirección General de Minas.

[51] Cushman, J. A., \& Stainforth, R. M. (1951). Tertiary Foraminifera of Coastal Ecuador: Part I, Eocene. Journal of Paleontology. https://doi.org/10.2307/1299795

[52] Alvarez, A., \& Linares, E. (1979). Edades K/Ar del Batolito de Piedrancha y el Stock de Arboledas, Departamento de Nariño. Departamento de Ciencias de La Tierra, Facultad de Ciencias, Universidad Nacional de Colombia, Publicacion Especial, Geologia, 22, 113-118.

[53] Spikings, R. A., Seward, D., Winkler, W., \& Ruiz, G. M. (2000). Low-temperature thermochronology of the Northern Cordillera Real, Ecuador: Tectonic insights from zircom and apatite fission track analysis. Tectonics. https://doi.org/10.1029/2000TC900010

[54] Aspden, J. A., McCourt, W. J., \& Brook, M. (1987). Geometrical control of subduction-related magmatism: the Mesozoic and Cenozoic plutonic history of western Colombia. Journal of the Geological Society. https://doi. org/10.1144/gsjgs.144.6.0893

[55] Barrero, D. (Ingeominas). (1979). Geology of the central Western Cordillera west of Buga and Roldanillo, Colombia. Publicación Geológica Especial Del Ingeominas, 4, $75 \mathrm{p}$.

[56] Chiaradia, M., \& Fontboté, L. (2001). Radiogenic lead signatures in Au-Rich volcanic-hosted massive sulfide ores and associated volcanic rocks of the early Tertiary Macuchi Island arc (Western Cordillera of Ecuador). Economic Geology. https://doi.org/10.2113/ gsecongeo.96.6.1361

[57] Duque-Caro, H. (1990). The choco block in the northwestern corner of South America: Structural, tectonostratigraphic, and paleogeographic implications. Journal of South American Earth Sciences. https://doi. org/10.1016/0895-9811(90)90019-W

[58] Métivier, F., \& Gaudemer, Y. (1997). Mass transfer between eastern Tien Shan and adjacent basins central Asia): constraints on regional tectonics and topography. Geophysical Journal International. https:// doi.org/10.1111/j.1365-246x.1997.tb04068.x

[59] Steckler, M. S., \& Watts, A. B. (1978). Subsidence of the Atlantic-type continental margin off New York. Earth and Planetary Science Letters. https://doi. org/10.1016/0012-821X(78)90036-5

[60] Rider, M. H., \& Kennedy, M. (2011). The geological interpretation of well logs: Rider-French Consulting. In Rider-French Consulting Ltd.

[61] Haq, B. U., Hardenbol, J., \& Vail, P. R. (1987). Chronology of fluctuating sea levels since the Triassic. Science. https://doi.org/10.1126/science.235.4793.1156

[62] Westerhold, T., Bickert, T., \& Röhl, U. (2005). Middle to late Miocene oxygen isotope stratigraphy of ODP site 1085 (SE Atlantic): New constrains on Miocene climate variability and sea-level fluctuations. Palaeogeography, Palaeoclimatology, Palaeoecology. https://doi.org/10.1016/j.palaeo.2004.12.001

[63] Cooper, M., Addison, F., \& Alvarez, R. (1995). Basin Development and Tectonic History of theLlanos Basin, Colombia. Petroleum Basins of South America.

[64] Echeverría, L. M. (1980). Tertiary or Mesozoic komatiites from Gorgona Island, Colombia: Field relations and geochemistry. Contributions to Mineralogy and Petrology. https://doi.org/10.1007/BF00381444

[65] Serrano, L., Ferrari, L., Martínez, M. L., Petrone, C. M., \& Jaramillo, C. (2011). An integrative geologic, geochronologic and geochemical study of Gorgona Island, Colombia: Implications for the formation of the Caribbean Large Igneous Province. Earth and Planetary Science Letters. https://doi.org/10.1016/j.epsl.2011.07.011

[66] Villagómez Díaz, D. R. (2010). Thermochronology, geochronology and geochemistry of the Western and Central cordilleras and Sierra Nevada de Santa Marta, Colombia: The tectonic evolution of NW South America. Faculté Des Sciences.

67] Luzieux, L. D. A., Heller, F., Spikings, R., Vallejo, C. F., \& Winkler, W. (2006). Origin and Cretaceous tectonic history of the coastal Ecuadorian forearc between $1^{\circ} \mathrm{N}$ and $3^{\circ} \mathrm{S}$ : Paleomagnetic, radiometric and fossil evidence. Earth and Planetary Science Letters. https://doi.org/10.1016/j. epsl.2006.07.008

[68] Daly, M. C. (1989). Correlations between Nazca/ Farallon Plate kinematics and forearc basin evolution in Ecuador. Tectonics. https://doi.org/10.1029/ TC008i004p00769

69] Pilger, R. H. (1984). Cenozoic plate kinematics, subduction and magmatism: South American Andes. Journal of the Geological Society. https://doi.org/10.1144/ gsjgs.141.5.0793

[70] Martinez, J. O., Gonzalez, J. L., Pilkey, O. H., \& Neal, W. J. (1995). Tropical barrier islands of Colombia's Pacific coast. Journal of Coastal Research.

[71] Gómez, J. (Ingeominas), Nivia, A. (Ingeominas), Montes, N. E. (Ingeominas), Jiménez, D. M. (Ingeominas), Tejada, M. L. (Ingeominas), Sepúlveda, M. J. (Ingeominas), Osorio, J. A (Ingeominas), Gaona, T. (Ingeominas), \& Diederix, H. (Ingeominas). (2007). Mapa Geológico de Colombia (p. 2 hojas). Ingeominas.

[72] Cediel, F., Shaw, R. P., \& Cáceres, C. (2005). Tectonic assembly of the Northern Andean Block. In AAPG Memoir.

[73] INGEOMINAS. (1983). Mapa de terrenos geológicos de Colombia. Publicación Geológica Especial Del Ingeominas, 14-I, 1-235.

[74] Moreno-Sanchez, M., \& Pardo-Trujillo, A. (2005). Stratigraphical and sedimentological constraints on western Colombia: Implications on the evolution of the Caribbean plate. In AAPG Memoir.

[75] López, E. (2004). Deep crust models of Colombia.

76] Kellog, J. N. and Vega, V. (1995). Tectonic development of Panama, Costa Rica, and the Colombian Andes: constraints from global positioning system geodetic studies and gravity. Geologic and Tectonic Development of the Caribbean Plate Boundary in Southern Central America.

[77] Busby, C. J., \& Ingersoll, R. V. (1995). Tectonics of sedimentary basins. Tectonics of Sedimentary Basins. https://doi.org/10.1016/s0037-0738(96)00004-8

[78] Tibaldi, A., Rovida, A., \& Corazzato, C. (2007). Late Quaternary kinematics, slip-rate and segmentation of a major Cordillera-parallel transcurrent fault: The Cayambe-Afiladores-Sibundoy system, NW South America. Journal of Structural Geology. https://doi. org/10.1016/j.jsg.2006.11.008

[79] Tibaldi, A., \& Romero, J. (2000). Morphometry of ate Pleistocene-Holocene faulting and volcanotectonic relationship in the southern Andes of Colombia. Tectonics. https://doi.org/10.1029/1999TC900063

80] Wang, K., \& Hu, Y. (2006). Accretionary prisms in subduction earthquake cycles: The theory of dynamic Coulomb wedge. Journal of Geophysical Research: Solid Earth. https://doi.org/10.1029/2005JB004094

[81] Collot, J. Y., Marcaillou, B., Sage, F., Michaud, F. Agudelo, W. Charvis, P Graindorge, D. Gutscher, M. A., \& Spence, G. (2004). Are rupture zone limits of great subduction earthquakes controlled by upper plate structures? Evidence from multichannel seismic reflection data acquired across the northern Ecuador-southwest Colombia margin. Journal of Geophysical Research: Solid Earth. https://doi. org/10.1029/2004JB003060

[82] Kanamori, H., \& McNally, K. C. (1982). VARIABLE RUPTURE MODE OF THE SUBDUCTION ZONE ALONG
THE ECUADOR-COLOMBIA COAST. Bulletin of the Seismological Society of America.

[83] Kelleher, J. A. (1972). Rupture zones of large South American earthquakes and some predictions. Journal of Geophysical Research. https://doi.org/10.1029/ jb077i011p02087

[84] Yepes, H., Audin, L., Alvarado, A., Beauval, C. Aguilar, J., Font, Y., \& Cotton, F. (2016). A new view for the geodynamics of Ecuador: Implication in seismogenic source definition and seismic hazard assessment. Tectonics. https://doi.org/10.1002/2015TC003941

[85] Pardo-Casas, F., \& Molnar, P. (1987). Relative motion of the Nazca (Farallon) and South American Plates since Late Cretaceous time. Tectonics. https://doi.org/10.1029/ TC006i003p00233

[86] Moxon, I. W., \& Graham, S. A. (1987). History and controls of subsidence in the Late Cretaceous - Tertiary Great Valley forearc basin, California ( USA). Geology. https://doi.org/10.1130/0091-7613(1987)15<626:HAC $\mathrm{OSI}>2.0 . \mathrm{CO} \cdot 2$

[87] Vannucchi, P., Galeotti, S., Clift, P. D., Ranero, C. R., \& von Huene, R. (2004). Long-term subduction-erosion along the Guatemalan margin of the Middle America Trench. Geology. https://doi.org/10.1130/G20422.1

[88] Meschede, Martin, \& Frisch, W. (1998). A platetectonic model for the Mesozoic and Early Cenozoic history of the Caribbean plate. Tectonophysics. https:// doi.org/10.1016/S0040-1951(98)00157-7

[89] Lonsdale, P. (2005). Creation of the Cocos and Nazca plates by fission of the Farallon plate. Tectonophysics. https://doi.org/10.1016/j.tecto.2005.05.011

[90] Lonsdale, P., \& Klitgord, K. D. (1978). Structure and tectonic history of the eastern Panama Basin. Bulletin of the Geological Society of America. https:/ doi.org/10.1130/0016-7606(1978)89<981:SATHOT> 2.0.CO;2

[91] Bostock, M. G., Hyndman, R. D., Rondenay, S., \& Peacock, S. M. (2002). An inverted continental moho and serpentinization of the forearc mantle. Nature. https: / doi.org/10.1038/417536a

[92] Meschede, M., \& Barckhausen, U. (2000). Plate tectonic evolution of the Cocos-Nazca spreading center. https://doi.org/10.2973/odp.proc.sr.170.009.2000

[93] Marcaillou, B. (2003). Régimes tectoniques et thermiques de la marge Nord Equateur - Sud Colombie $\left(0^{\circ}-3,5^{\circ} N^{\circ}\right)$ - Implications sur la sismogènese. Université Pierre et Marie Curie, Paris.

[94] INGEOMINAS. (2002). Atlas Colombiano de información geológico-minera para inversión - ACIGEMI - Mapa de anomalías Gravimétricas de Colombia. INGEOMINAS

[95] Gradstein, F. M., \& Ogg, J. G. (2004). Time Scale. In Encyclopedia of Geology. https://doi.org/10.1016/BO-12 369396-9/00070-8

[96] Feininger, T. (1975). Mapa gravimétrico Bouguer del Ecuador (1:1'000.000)

[97] Fairhead, J. D., Chevalier, P., Green, C. N., Hunt, N. J., Manton, D. C., Spink, S. J., Stuart, G., \& Windle, I. D. (1991) No Colombia gravity anomaly map - South American Gravity project (SAGP). Scale 1:2'000.000.

[98] Collot, J. Y., \& TEAM, A.-C. (2005). The Amadeus cruise, Ecuador - Colombia.

[99] Baldwin, B., \& Butler, C. O. (1985). COMPACTION CURVES. American Association of Petroleum Geologists Bulletin. https://doi.org/10.1306/ad462547-16f7-11d78645000102c1865d 